\title{
The Aeromonas salmonicida subsp. salmonicida exoproteome: determination of the complete repertoire of Type-Three Secretion System effectors and identification of other virulence factors
}

Philippe Vanden Bergh ${ }^{1}$, Manfred Heller ${ }^{2}$, Sophie Braga-Lagache ${ }^{2}$ and Joachim Frey ${ }^{1 *}$

\begin{abstract}
Background: Aeromonas salmonicida subsp. salmonicida, the etiologic agent of furunculosis, is a major pathogen of fisheries worldwide. Several virulence factors have been described, but the type-three secretion system (T3SS) is recognized as having a major effect on virulence by injecting effectors directly into fish cells. In this study we used high-throughput proteomics to display the differences between in vitro secretome of A. salmonicida wild-type (wt, hypervirulent, JF2267) and T3SS-deficient (isogenic $\triangle a s C V$, extremely low-virulent, JF2747) strains in exponential and stationary phases of growth.

Results: Results confirmed the secretion of effectors AopH, AexT, AopP and AopO via T3SS, and for the first time demonstrated the impact of T3SS in secretion of Ati2, AopN and ExsE that are known as effectors in other pathogens. Translocators, needle subunits, Ati1, and AscX were also secreted in supernatants (SNs) dependent on T3SS. AopH, Ati2, AexT, AopB and AopD were in the top seven most abundant excreted proteins. EF-G, EF-Tu, DnaK, HtpG, PNPase, PepN and MdeA were moderately secreted in wt SNs and predicted to be putative T3 effectors by bioinformatics. Pta and ASA_P5G088 were increased in wt SNs and T3-associated in other bacteria. Ten conserved cytoplasmic proteins were more abundant in wt SNs than in the $\triangle a s c V$ mutant, but without any clear association to a secretion system. T1-secreted proteins were predominantly found in wt SNs: OmpAl, OmpK40, DegQ, insulinase ASA_0716, hypothetical ASA_0852 and ASA_3619. Presence of T3SS components in pellets was clearly decreased by ascV deletion, while no impact was observed on T1- and T2SS. Our results demonstrated that the $\triangle$ ascV mutant strain excreted well-described (VapA, AerA, AerB, GCAT, Pla1, PlaC, TagA, Ahe2, GbpA and enolase) and yet uncharacterized potential toxins, adhesins and enzymes as much as or even more than the wt strain. Other putative important virulence factors were not detected.
\end{abstract}

Conclusions: We demonstrated the whole in vitro secretome and T3SS repertoire of hypervirulent A. salmonicida. Several toxins, adhesins and enzymes that are not part of the T3SS secretome were secreted to a higher extent in the extremely low-virulent $\triangle \mathrm{Aas} C \mathrm{~V}$ mutant. All together, our results show the high importance of an intact T3SS to initiate the furunculosis and offer new information about the pathogenesis.

\footnotetext{
* Correspondence: joachim.frey@vetsuisse.unibe.ch

${ }^{1}$ Institute of Veterinary Bacteriology, University of Bern, Länggassstrasse 122,

Bern, Switzerland

Full list of author information is available at the end of the article
}

\section{Biomed Central}

(c) 2013 Vanden Bergh et al.; licensee BioMed Central Ltd. This is an open access article distributed under the terms of the Creative Commons Attribution License (http://creativecommons.org/licenses/by/2.0), which permits unrestricted use, distribution, and reproduction in any medium, provided the original work is properly cited. 


\section{Background}

Aeromonas salmonicida subsp. salmonicida, a gramnegative bacterium, is the etiologic agent of furunculosis, a frequent and major pathogen of fisheries worldwide which is generating significant economic losses related to deficits in zootechnical profits and the intensive use of antibiotics [1]. To date, several virulence factors have been characterized for $A$. salmonicida: the type three secretion system (T3SS) encoded on a large plasmid and described for the first time in the Aeromonas genus in our laboratory ten years ago [2,3]; the surface layer protein VapA [4]; a type I pilus [5]; three type IV pilus systems [6,7]; superoxide dismutases [8] and some extracellular proteins including serine protease (AspA) [9], glycerophospholipid:cholesterol acyltransferase (GCAT or SatA) $[9,10]$ and several hemolysins (aerolysins) [11]. Other putative virulence factors were identified without experimental evidence [12]. However, the T3SS is the only one recognized as having a major effect on virulence, as independent studies have shown that isogenic mutant strains for T3SS structural proteins are non-virulent both in vitro and in vivo [2,13-16]. T3SS is also called "injectisome" because it enables the secretion and simultaneous injection of effector proteins produced in the prokaryotic cytoplasm across the bacterial envelope and then, through a needle and a translocon complex, into the target eukaryotic cells across their membrane [17]. Once injected in the eukaryotic cytosol, effector proteins are able to modulate cell signalling pathways, or alternatively disrupt the dynamics of the cytoskeleton, thereby modulating host cell biology for the benefit of the pathogen [17].

Currently, four different virulent effectors have been investigated for the A. salmonicida T3SS, and only two have been studied in detail: the bifunctional toxin AexT, which possesses a GTPase-activating domain acting on small monomeric GTPases of the Rho family and an ADP-ribosylating domain, which ADP-ribosylates both muscular and non-muscular actin [18,19]; AopP, which inhibits the $\mathrm{NF}-\kappa \mathrm{B}$ signaling pathway by preventing translocation of NF- $k$ B into the nucleus of the target cells [20]. AopO, which is related to Yersinia YopO/YpkA [14] and AopH with similarity to Yersinia YopH [14], represent two further potential effectors that have been characterized in less detail. AexT, AopO and AopH toxins do not seem to be solely responsible for Aeromonas virulence because individual knock-out mutations of these genes [14] or a triple-effector knock-out mutant [21] keep a virulent phenotype or show only delayed virulence, such as in the case of $\Delta a e x T$ mutants [14,19]. Given that A. salmonicida mutants that are defective for T3SS fully lose their pathogenicity, we hypothesize that other important cytotoxic proteins might be injected by these Aeromonas nanosyringes into the fish cell cytoplasm.
The aim of this work was to use high-throughput proteomics to display the secretome of A. salmonicida subsp. salmonicida wild-type (wt, hypervirulent) and an isogenic T3SS-deficient mutant ( $\triangle a s c V$, extremely lowvirulent) during the exponential-growth phase (GP) and the stationary phase (SP). In this article, which is the second part of the work, authors characterized the whole in vitro repertoire of T3SS effectors and new virulence factors of A. salmonicida. In the first part, "The Aeromonas salmonicida subsp. salmonicida exoproteome: global analysis, moonlighting proteins and putative antigens for vaccination against furunculosis", the same authors focused on the general analysis of proteomics data, the presence of cytoplasmic proteins with putative moonlighting activities in supernatants and the identification of putative antigens for fish vaccination against furunculosis.

\section{Results and discussion}

A. salmonicida T3SS and comparison to other appendages A. salmonicida subsp. salmonicida wt strain was previously shown to cause $80 \%-100 \%$ mortality in rainbow trout at $500 \mathrm{cfu}$ inoculated intraperitoneally, while the $\triangle a s c V$ deletion mutant derived thereof was shown to be non-virulent causing $0 \%$ mortality under the same conditions $[15,22]$. In order to further show the strong attenuation due to the $\Delta a s c V$ deletion mutation, rainbow trout kept under the same conditions were challenged intraperitoneally with $10^{8} \mathrm{cfu}$, an infectious dose which is not representative of what happens in natural infection. These fish showed only a slight mortality of $20 \%$ after 14 days post infection showing the high degree of attenuation obtained with the $\triangle a s c V$ mutation. We assume that the residual mortality observed in this experiment is solely due to the excessive load of bacteria applied.

We identified a total of 2136 A. salmonicida proteins with PMSS and LFQ values among the different experimental conditions (see Methods for explanations and the first part of this work for raw data) for 1861 and 2070 proteins respectively. These values correspond to a semi-quantitative abundance estimate of protein species present in SDS-PAGE gels and were used as a surrogate for the amount of secreted proteins in concentrated SNs and the amount of produced proteins in whole pellets.

In our MS analysis we identified 45 proteins of the A. salmonicida T3SS. The effectors should only be secreted or detected in higher quantity in wt SNs (in GP and SP) in comparison to the $\triangle a s c V$ mutant (Table 1). Our results confirmed the secretion of the well-described AopH, AexT, AopP and AopO effectors (Figure 1, Table 1). Moreover, we demonstrated the secretion of additional T3SS effectors for the first time. Ati2 (ASA_P5G045), an inositol polyphosphate 5-phosphatase already described as a putative T3SS effector [12], was strongly 
Table 1 Secreted components of the A. salmonicida T3SS

Locus Uniprot Name Description

Fold change in

SNs $\log _{2} \mathrm{wt} / \mathrm{mut}$

[PMSS] $^{1}$ and [LFO

GP

GP $\quad$ SP

Unique peptides $]^{3}$

\section{Effectors}

ASA_P5G009 G7D171 AopH Putative tyrosine phosphatase

\begin{tabular}{|c|c|c|c|c|c|c|c|c|c|c|c|c|}
\hline $4.06^{1}$ & 3.07 & $62^{3}$ & 37 & 67 & 61 & $0.00 E+00$ & $0.00 E+00$ & $\mathrm{n}$ & y & $\mathrm{n}$ & $n$ & PF00102 \\
\hline $9.36^{2}$ & 8.25 & $2753^{4}$ & 288 & 7348 & 2155 & & & & & & & \\
\hline 4.41 & 3.61 & 60 & 41 & 51 & 46 & $0.00 E+00$ & $0.00 E+00$ & y & y & $n$ & $n$ & PF03372 \\
\hline 6.78 & 9.27 & 3078 & 339 & 4161 & 521 & & & & & & & \\
\hline 3.91 & 2.99 & 51 & 34 & 45 & 43 & $0.00 E+00$ & $0.00 E+00$ & y & y & $n$ & $n$ & PF01129 \\
\hline 7.78 & 9.09 & 2178 & 315 & 4530 & 708 & & & & & & & \\
\hline 3.46 & 3.34 & 27 & 14 & 23 & 19 & $4.12 \mathrm{E}-284$ & $0.00 E+00$ & $y$ & $y$ & $\mathrm{n}$ & $\mathrm{n}$ & - \\
\hline 5.01 & 7.46 & 281 & 70 & 138 & 18 & & & & & & & \\
\hline 10.34 & 6.46 & 40 & 7 & 53 & 33 & $5.48 \mathrm{E}-235$ & $0.00 E+00$ & y & y & $n$ & $\mathrm{n}$ & cd06612 \\
\hline 11.93 & 12.38 & 94 & 0 & 483 & 4 & & & & & & & \\
\hline 4.53 & 2.72 & 17 & 10 & 23 & 19 & 1.69E-209 & $0.00 E+00$ & y & $n$ & $n$ & $n$ & - \\
\hline 6.82 & 6.70 & 178 & 22 & 455 & 73 & & & & & & & \\
\hline 4.52 & 3.52 & 9 & 4 & 10 & 9 & 2.73E-106 & $2.98 \mathrm{E}-113$ & $n$ & $n$ & $n$ & $n$ & - \\
\hline 5.85 & 8.56 & 51 & 7 & 101 & 37 & & & & & & & \\
\hline 6.77 & 2.88 & 21 & 11 & 16 & 13 & $0.00 \mathrm{E}+00$ & $0.00 E+00$ & y & y & $n$ & $n$ & - \\
\hline 11.12 & 6.11 & 428 & 16 & 381 & 34 & & & & & & & \\
\hline 4.06 & 3.07 & 24 & 13 & 31 & 26 & $0.00 \mathrm{E}+00$ & $0.00 \mathrm{E}+00$ & y & y & $n$ & $\mathrm{n}$ & - \\
\hline 7.59 & 8.98 & 322 & 26 & 1377 & 158 & & & & & & & \\
\hline 10.13 & 3.77 & 28 & 8 & 30 & 26 & $6.61 \mathrm{E}-233$ & $0.00 E+00$ & $n$ & y & $n$ & $n$ & - \\
\hline 10.54 & 9.59 & 85 & 0 & 391 & 50 & & & & & & & \\
\hline 0 & 4.81 & 3 & 2 & 5 & 3 & $9.26 \mathrm{E}-13$ & $5.80 \mathrm{E}-22$ & $n$ & $n$ & $n$ & $\mathrm{n}$ & PF13414 \\
\hline 6.30 & 4.94 & 7 & 1 & 10 & 1 & & & & & & & \\
\hline 6.19 & 7.48 & 7 & 3 & 9 & 6 & $1.26 \mathrm{E}-105$ & $9.02 \mathrm{E}-226$ & $\mathrm{n}$ & y & $n$ & $n$ & - \\
\hline 4.07 & 8.05 & 12 & 0 & 46 & 0 & & & & & & & \\
\hline
\end{tabular}

PEP GP

PEP SP

Modla

$(>0.4) \quad(>0.95)$

Eukaryotic

domain

\begin{tabular}{llll}
\hline wt & mut & wt & mut \\
GP & GP & SP & SP
\end{tabular}

ASA_P5G045 A4SUE7 Ati2 Inositol polyphosphate 5-phosphatase

ASA_4266 G7D0E2 AexT GTPase, ADPribosylase

pAsal1_03 G7D197 AopP Inhibition of NF-kB translocation in nucleus

ASA_P5G098 G7D0W5 AopO Putative serine/threonine kinase

ASA_P5G075 A4SUH7 AopN Secretion control of translocators and immune suppressor

ASA_P5G062 A4SUG4 ExsE Regulator, chaperone for ExsC

\section{Translocon}

ASA_P5G065 A4SUG7 AopB Translocon, Hydrophobic translocators, Pore in host cell

ASA_P5G064 A4SUG6 AopD Translocon, Hydrophobic translocators, Pore in host cell

ASA_P5G067 A4SUG9 AcrV Middle substrate, tip translocon, Hydrophilic translocators, Protective antigen, anti-host factor

ASA_P5G066 A4SUG8 AcrH Chaperone for AopB/AopD

\section{Needle}

ASA_P5G054 A4SUF6 AscF Early substrate, needle subunit $\begin{array}{llllll}4.07 & 8.05 & 12 & 0 & 46 & 0\end{array}$ 
Table 1 Secreted components of the A. salmonicida T3SS (Continued)

ASA_P5G078 A4SUI0 AsCP Needle length control, Ruler protein, 7.41 specifity switch

4.32
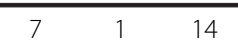

$3.21 \mathrm{E}-68$

$0.00 \mathrm{E}+00 \mathrm{y}$

y

n

n

ASA_P5G052 A4SUF4 AscH Regulator needle assembling

Others

ASA_P5G046 A4SUE8 Ati1 Chaperone Ati2

$\begin{array}{llllll}7.35 & 8.85 & 12 & 0 & 19 & 14 \\ 25.77 & 8.04 & 17 & 0 & 100 & 6\end{array}$

7.89E-31 1.86E-101 y

n

$\begin{array}{lllll}7.11 & 5.62 & 7 & 2 & 3 \\ 6.83 & 25.49 & 10 & 0 & 8\end{array}$

ASA_P5G072 A4SUH4 AscX Unknown function, chaperoned by AscY 5.51

$\begin{array}{llllll}20.64 & 25.43 & 4 & 0 & 11 & 0\end{array}$

The table shows fold changes for GP and SP in SNs (Log base 2 [wt/mut]) for PMSS and LFQ values, unique peptides, MS/MS Counts, PEP values, prediction for T3-effectors (Modlab and Effective) and secretion by alternative systems (SignalP and TatP), and the presence of eukaryotic domains in the protein. 


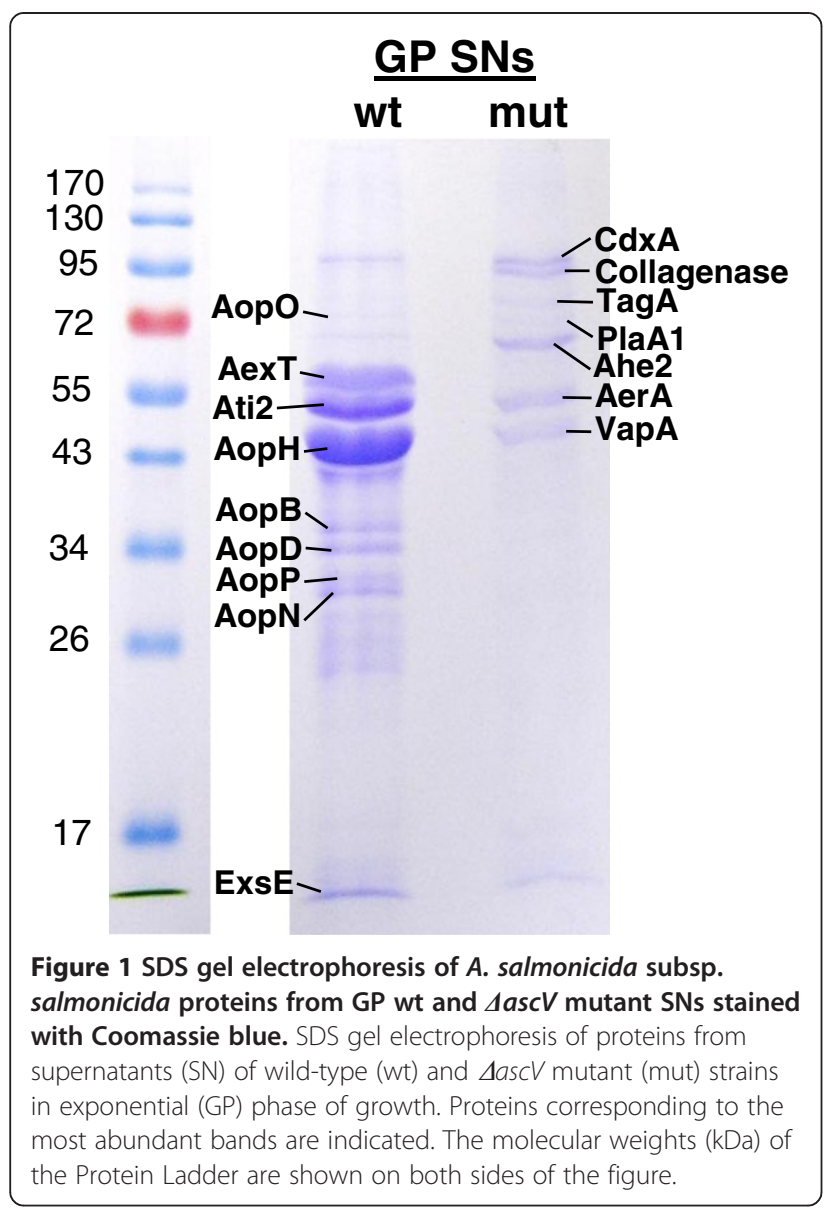

secreted in wt SNs (as much as AexT, 20 times more than in $\Delta a s c V$ mutant $\mathrm{SN})$. Ati2 is homologous to the Vibrio parahaemolyticus T3SS effector VPA0450 and Photorhabdus luminescens Plu4615 (87\% identity over 495 amino acids [aa]). This effector disrupts cytoskeletal binding sites on the inner surface of host membranes, causes plasma membrane blebbing and probably contributes to cell death by facilitating lysis [23]. Our data showed that Ati1 (ASA_P5G046), the chaperone of Ati2, was also secreted in wt SNs by the T3SS, whereas all other T3SS chaperones (SycE, SycH, SycO, AscY, Acr1, Acr2, AscB, AcrG, AscG, AscE, AscO and AcrR) were only present in pellets and were never secreted (Figure 2) suggesting that Ati1 might be injected with Ati2 into fish cells. AopN (ASA_P5G075) was secreted by the T3SS in wt SNs, but to a lower extent than the previous effectors. AopN homologues in other bacteria are T3SS effectors which play a role in virulence and can have a dual role: controlling the secretion of translocator proteins inside bacteria and suppressing immunity when T3 translocated inside host cells [24-26].

AopH, Ati2 and AexT were the most secreted $A$. salmonicida proteins in wt SNs (GP or SP) (Figure 1, Additional files 1 and 2). When we calculated the ratio

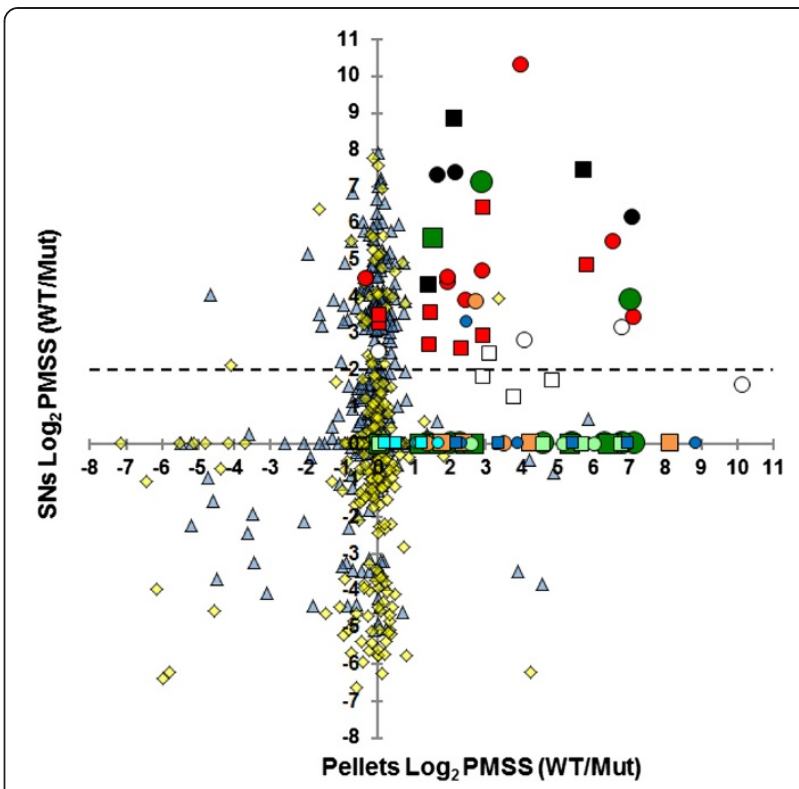

Figure 2 Ratios of different T3SS components in A. salmonicida wt versus mutant strain. The plot represents the logarithm base two of the ratios [wt/mut] PMSS values for each protein identified in pellet (X-axis) and SNs (Y-axis). For T3SS components, exponential growth phase (GP) values are represented by circles and stationary phase (SP) values by squares. Red, the T3SS effectors; dark green, T3SS chaperones; white, translocators; black, needle components; orange, OM secretin ring; light green, IM export ring; dark blue, C ring ATPase; light blue, transcriptional regulators. Values of other proteins in GP and SP are shown with dark blue triangles and yellow squares respectively. The hatched line represents the threshold that we used to identify proteins 4 -fold more present in wt SNs.

of [SN/pellet] quantities for each effector, we observed that AopP, AopH, AexT and Ati2 showed a high proportion in concentrated SNs, whereas this proportion was weak for AopO and AopN. This suggests that the in vitro secretion of AopO and AopN in wt SNs was significantly less efficient than AopP, AopH, AexT and Ati2.

We observed that AscX (ASA_P5G072) and ExsE (ASA_P5G062) were T3 secreted in wt SNs (Table 1). The same observation was made for YscX in Yersinia pestis [27]. YscX does not seem to be a T3SS effector, but it plays a role with its chaperone (YscY) and YscV in the export of needle components (YscF and YscI) [28]. In Pseudomonas aeruginosa, it was shown that the T3 secretion in extracellular medium and the T3 translocation into host cell of ExsE was required for transcriptional induction of the T3SS [29-31]. It is not known whether ExsE plays a role within the host cell.

Our proteomic analysis logically detected all translocon components (AopB, AopD, AcrV and AcrH) in $A$. salmonicida wt secretome (Figures 1 and 2, Table 1). AopB and AopD were among the top ten most abundant secreted proteins (Additional file 2). As expected, the elements of the T3SS needle (AscF, AscP, AscH and AscI) were also 
oversecreted in wt SNs and T3SS proteins of the OM ring (Asc), AscD, AscC and ExsB), the inner membrane export apparatus (AscV, AscR, AscT and $\mathrm{Asc} \mathrm{U}$ ) and the $\mathrm{C}$ ring/ ATPase (AscL, AscK, AscN and AscQ) were only detected in pellets (Figure 2 and Additional files 1, 2 and 3).

Our study did not detect T3SS effectors AopX (homologuous to V. parahaemolyticus VopR [VP1683], P. luminescens plu4750) and ASA_0010 (homologuous to $V$. parahaemolyticus VopS [VP1686]) [32], suggesting that the mutations present in these genes in the genome of A. salmonicida A449 [12] and also in our wt strain prevent their production. However, the chaperone of VopS effector (ASA_0011) was detected, but only to a weak level in GP in the wt pellet.

From these results we concluded that our MS analysis localized $100 \%$ of T3SS components that are structurally linked to the bacteria and associated to pellets (cytoplasmic chaperones, OM, IM and C rings proteins) or T3 secreted and associated to SNs (effectors, translocon and needle elements) with effectiveness and accuracy. These results also support the idea that highly conserved cytoplasmic proteins unexpectedly present in A. salmonicida SNs and detailed in the first part of this work were not due to cell lysis.

The quantity of T3SS proteins was systematically lower in SP pellets (wt or mutant), and significantly lower in mutant pellets in comparison to wt (Additional files 1 and 3 for individual T3SS components), suggesting that the T3SS production was at a maximum when bacteria were in the phase of active multiplication and that the $\Delta a s c V$ knock-out mutation induced a strong down-regulation of the expression of many T3SS genes. AopD, AopB, AopH, AscV, Ati2, AcrV, AopO and AexT were the most abundant T3SS proteins present in the GP wt pellet (Additional file 3) and the difference in quantity (PMSS value) observed between the pellets of the wt and the $\triangle a s c V$ mutant in GP was confirmed by western blotting for AopD, AcrV and AexT (Additional file 4).

This underexpression of T3SS genes from different operons argues that the asc $V$ deletion modulates the transcription regulation of several T3SS components and is not due to a polar effect. Strickingly, weak amounts of T3SS effectors/translocators were found in $\triangle a s c V$ mutant SNs (AopH, AexT, AopD, Ati2, AopP, AopN, AopB and ExsE by order of decreasing importance), but clearly to a lower extent than in wt SNs (Figure 3A and Additional files 1 and 2). As for the wt strain, the presence of these T3SS elements in mutant SNs was unlikely to be due to bacterial lysis given that (referred to the first part of this work for details): (i) 90\% of predicted cytoplasmic proteins in mutant pellets were never detected in SNs, (ii) GroEL, a marker of cell lysis, was among the most abundant proteins present in mutant pellets but was absent from SNs, and (iii) EF-Tu amount in mutant SNs decreased from GP to SP. The presence of T3SS effectors/ translocators in mutant SNs was also unlikely to be due to a contamination between wt and mutant samples because, for example, the [wt/mutant] PMSS ratios of these T3SSsecreted components were 10-fold higher for AopP to 110-fold higher for AopB in GP SNs of wt when compared to $\triangle a s c V$ and were therefore not proportional. Burr and collaborators [2] did not detect AexT secretion in the $\triangle a s c V$ mutant SN, but they used unconcentrated SNs. Our samples were 200 times more concentrated in this study. When we used total sum of PMSS values to calculate [intrabacterial effectors or translocators/T3SS structural components] we found that proportions were similar in wt and mutant strains (Figure $3 \mathrm{~B}$ ) assuming that, even if $a s c V$ was deleted, A. salmonicida kept the same proportion between the intracellular stock of effectors/ translocators and the other T3SS structural components. As already mentioned, the proportion of [extrabacterial effectors or translocators/T3SS structural components] showed that the T3 secretion capacity was strongly impaired for the mutant strain during GP and SP, but this difference with the wt strain was weaker during the SP (Figures 3). This could mean that small amounts of effectors and translocators accumulated progressively in the mutant SNs along growth phases.

The mutant strain might continue to release these T3SS components in SNs, either from the resting structural T3SS components or by an alternative secretion pathway. Recent publications argue that the T3SS arose from an exaptation of the flagellum, i.e. the recruitment of part of the flagellum structure for the evolution of the new protein delivery function [33,34] and, the secretion of T3SS effectors through flagella in the extracellular medium has been described in other bacteria [35,36]. The secretion of effectors/translocators by this process is unlikely in A. salmonicida given that functional lateral and polar flagella were not detected (Figure 4), thus confirming the results of studies showing that operons coding for A. salmonicida flagella contain several mutations [12]. However, we could imagine that FlhA (ASA_1351, polar flagella) and/or LfhA (ASA_0352, lateral flagella), showing respectively $56 \%$ and $55 \%$ of similarity with AscV might partially supply the function of this T3SS component. Such possible interactions between FlhA and the T3SS have been described in Chlamydia pneumonia [37]. While no mutations are predicted in these genes in A. salmonicida their expression was not detected in our pellets, but we cannot exclude that they were expressed below the detection limit of our system as our proteomic analysis did not cover the total proteome (59\% of proteins common to all Aeromonas sp. were identified). Another possibility is that two mechanisms of effectors/translocators secretion operate in parallel along phases of growth, the first would be actively dependent on intact T3SSs while the second, clearly 


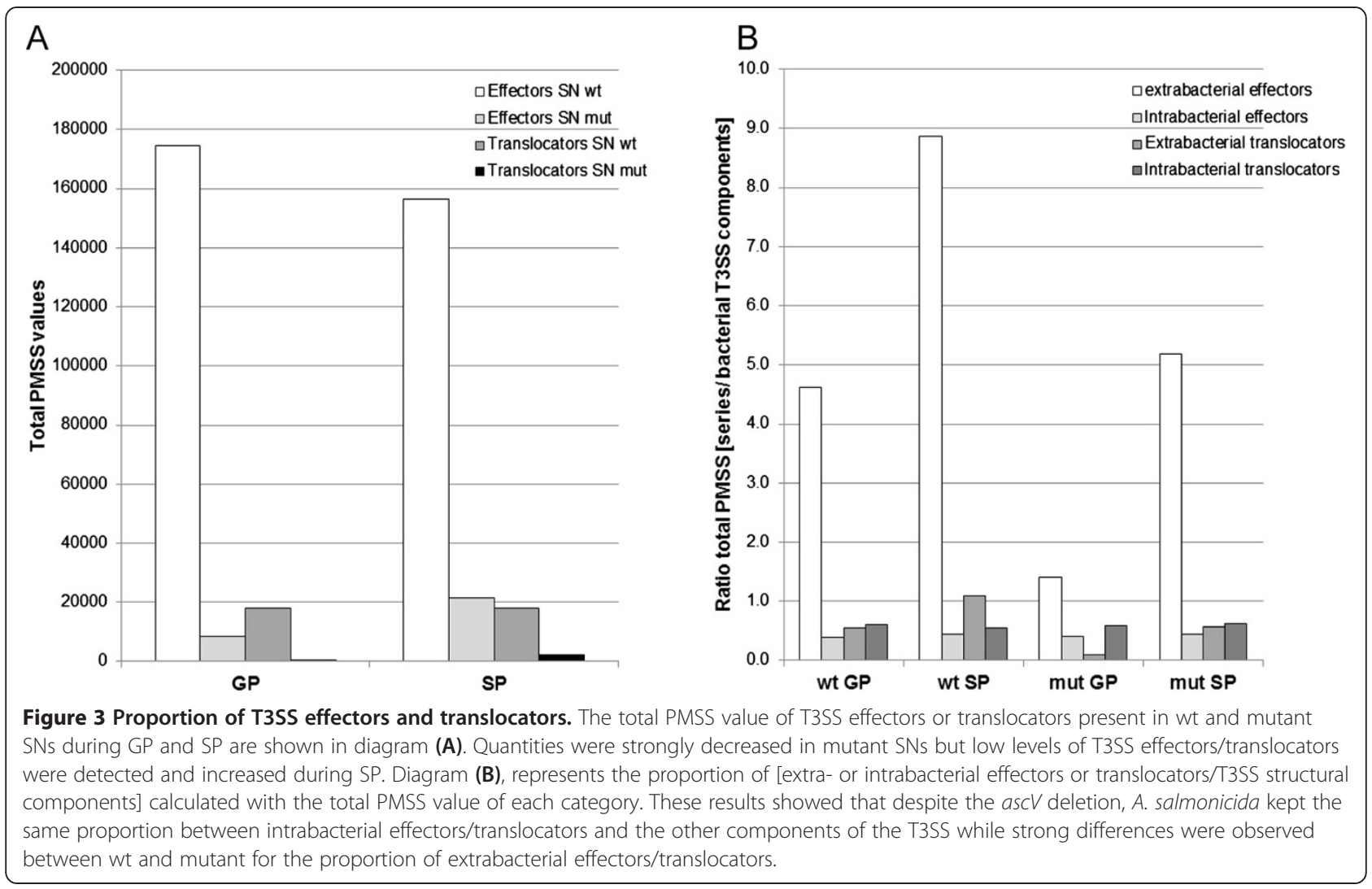

less efficient, would explain the progressive accumulation of effectors/translocators in the extracellular medium of the mutant strain. The alternative secretion of T3SS effectors through classical/unclassical pathways has never been described contrary to major constituents of the OM ring which are transported to the periplasm by the Sec-dependent secretion pathway [38]. Furthermore, the presence of T3SS effectors in the periplasma [39] and OMVs [40] has rarely been described. Another possibility might be the formation of double-bilayer OMVs (diameter from 100 to $250 \mathrm{~nm}$ ) containing cytosolic components, as recently described in Shewanella [41], but GroEL would have been detected in SNs. Another study showed that in the absence of the host cell, at least YopH (homologous to AopH), YopE (AexT) and YopB/YopD translocators were excreted homogeneously at the Yersinia surface without physical association with the injectisome [42]. While the T3-dependent secretion of effectors in $\mathrm{SNs}$ is wellcharacterized, it is not known if these OM-associated effectors are excreted at the bacterial surface through a T3SS-dependent pathway. As a result, further investigations are necessary to clarify this point.

When we compared the total LFQ values of $A$. salmonicida secretion systems (T1- to T6SS), flagella (lateral and polar), pili (T1 pilus [Fim], T4 pili [Tap, Flp and Msh] and fimbriae (MatB), it was clear that the T3SS was the most expressed system by $A$. salmonicida
(Figure 4). T1- and T2SS were expressed just as much in wt and mutant pellets, showing that their expression and function was not impaired by the knock-out mutation in ascV. All of the other systems (flagella, pili, fimbriae, T4-, T5- and T6SS) were either not expressed at all or were expressed to a lower level, suggesting that they could be impaired by mutations similar to the ones observed in the reference A449 strain [12].

\section{Other putative virulence factors oversecreted in A. salmonicida wt SNs}

We combined several thresholds to identify additional putative $A$. salmonicida T3SS effectors and T3-independent virulence factors. We targeted wt secreted proteins with PMSS values over 25, a PMSS or LFQ intensity 4-fold increased in the wt SN, and a PEP value inferior to $10^{-8}$ or equal to zero (Figure 2 and Table 2). We then performed bioinformatics analyses to predict whether a peptide signal for Sec-, Tat- or T3 dependent secretion was present in the $\mathrm{N}$-terminal part of secreted proteins.

From 466 proteins detected in SNs, only 26 proteins were more abundant in wt than in mutant SNs, while their presence was approximatively similar in pellets. Among the first targeted proteins, seven were surprisingly designated by bioinformatics as T3 effectors (EF-G, EF-Tu, DnaK, HtpG, PNPase, MdeA, PepN and OpdA), and two proteins without a predicted motif for T3 


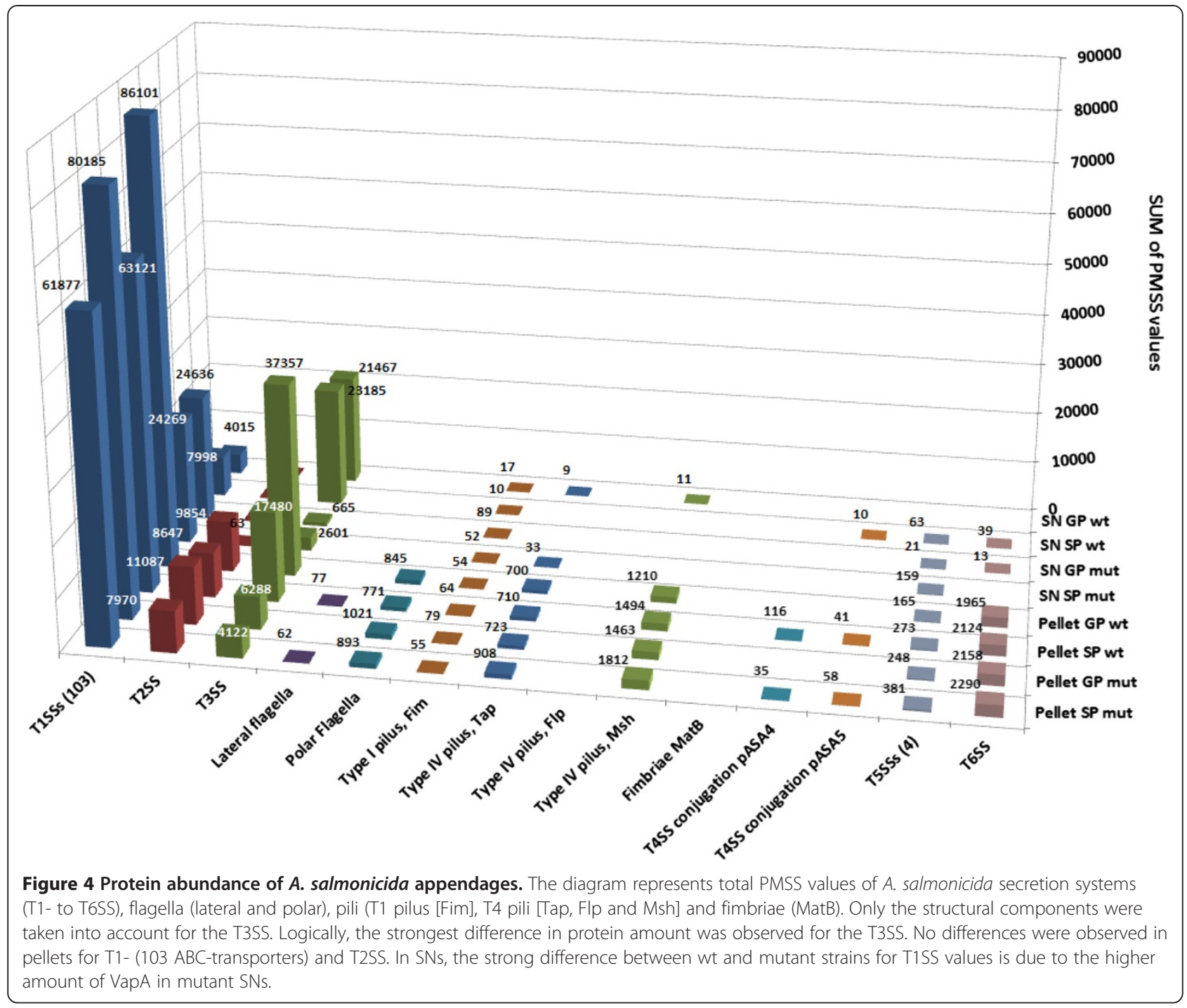

secretion were shown to have homologues that are T3 secreted in other bacteria (Pta and ASA_P5G088) (Table 2). These proteins were secreted to a clear lesser extent than previously described T3SS effectors, and these results should therefore be interpreted with caution and need further investigations in order to confirm that they are (T3-) secreted. Strikingly, homologues of these proteins are present in eukaryotic cells, where they play fundamental roles and sometimes alternative (moonlighting) functions (EF-1 $\alpha$ for EF-Tu [43], HSP70 and HSP90 for DnaK and HtpG [44-46], eukaryotic aminopeptidases and thimet oligopeptidase for PepN and OpdA [47-49]). For example, these molecular chaperones play a role in the virulence of other pathogens and are considered as new targets for therapy [50,51]. It is tempting to assume that EF-G, EF-Tu, DnaK, HtpG, PepN and OpdA might be injected by $A$. salmonicida into host cells in order to interfere with these functions.
Polynucleotide phosphorylase PNPase has pleiotropic roles in bacteria such as degrading mRNA (degradosome) and mediating post-transcriptional regulation [52]. However, it was shown that PNPase was required for the optimal functioning of Yersinia T3SS and enhanced the ability of the bacterium to withstand the killing activities of murine macrophages [53]. In Salmonella enterica and Dickeya dadantii, PNPase downregulated the transcription of T3SS genes $[54,55]$.

Although they did not have the $\mathrm{N}$-terminal motif for T3-secretion, the phosphate acetyl transferase (Pta, ASA_3402) and the putative $\alpha / \beta$ hydrolase ASA_P5G088 of $A$. salmonicida were targeted by our screening as putative T3SS effectors. In Salmonella, a Pta mutant showed that this enzyme was associated to virulence [56], and a recent study demonstrated that E. coli Pta (E2348C_2437, $83 \%$ similarity with $A$. salmonicida Pta) might be secreted by the T3SS [57]. Interestingly, homologues of 
Table 2 Oversecreted proteins by $A$. salmonicida wt strain

\begin{tabular}{|c|c|c|c|c|c|c|c|c|c|c|c|c|c|c|c|c|}
\hline \multirow[t]{2}{*}{ Locus } & \multirow[t]{2}{*}{ Uniprot } & \multirow[t]{2}{*}{ Name } & \multirow[t]{2}{*}{ Description } & \multicolumn{2}{|c|}{$\begin{array}{l}\text { Fold change in } \\
\text { SNs Log } \text { Logt }_{2} \text { mut) } \\
{[\mathrm{PMSS}]^{1} \text { and }[\mathrm{LFQ}]^{2}}\end{array}$} & \multicolumn{4}{|c|}{$\begin{array}{l}{\text { [Unique peptides }]^{3} \text { and }} \\
{\text { [MS/MS Count }]^{4}}\end{array}$} & \multirow[t]{2}{*}{ PEP GP } & \multirow[t]{2}{*}{ PEP SP } & \multirow[t]{2}{*}{$\begin{array}{l}\text { Modlab } \\
(>0.4)\end{array}$} & \multirow[t]{2}{*}{$\begin{array}{l}\text { Effective } \\
(>0.95)\end{array}$} & \multirow[t]{2}{*}{ SignalP } & \multirow[t]{2}{*}{ TatP } & \multirow[t]{2}{*}{$\begin{array}{l}\text { Eukaryotic } \\
\text { domain }\end{array}$} \\
\hline & & & & GP & SP & $\begin{array}{l}\text { wt } \\
\text { GP }\end{array}$ & $\begin{array}{l}\text { mut } \\
\text { GP }\end{array}$ & $\begin{array}{l}\text { wt } \\
\text { SP }\end{array}$ & $\begin{array}{l}\text { mut } \\
\text { SP }\end{array}$ & & & & & & & \\
\hline \multicolumn{17}{|c|}{ With a predicted signal for T3SS } \\
\hline \multirow[t]{2}{*}{ ASA_0292 } & \multirow[t]{2}{*}{ A4SHV8 } & \multirow[t]{2}{*}{ EF-G } & \multirow[t]{2}{*}{ Elongation factor $G$} & $2.42^{1}$ & 0.98 & $33^{3}$ & 25 & 41 & 40 & \multirow[t]{2}{*}{$0.00 \mathrm{E}+00$} & \multirow[t]{2}{*}{$0.00 E+00$} & \multirow[t]{2}{*}{ y } & \multirow[t]{2}{*}{$\mathrm{n}$} & \multirow[t]{2}{*}{$n$} & \multirow[t]{2}{*}{$n$} & \multirow[t]{2}{*}{-} \\
\hline & & & & $3.60^{2}$ & 1.27 & $73^{4}$ & 19 & 181 & 106 & & & & & & & \\
\hline ASA_0275 & A4SHU2 & EF-Tu & Elongation factor Tu & 1.03 & 1.08 & 24 & 21 & 24 & 23 & $2.98 \mathrm{E}-220$ & $0.00 \mathrm{E}+00$ & $\mathrm{n}$ & y & $\mathrm{n}$ & $\mathrm{n}$ & PF03143 \\
\hline ASA_0293 & & & & 2.49 & 2.15 & 52 & 34 & 118 & 81 & & & & & & & PF01926 \\
\hline ASA_2996 & A4SQ25 & Dnak & Chaperone protein DnaK & 2.91 & 0.85 & 30 & 22 & 37 & 37 & $2.28 \mathrm{E}-272$ & $0.00 E+00$ & y & $\mathrm{n}$ & $n$ & $\mathrm{n}$ & PF00012 \\
\hline & & & & 3.27 & 0.30 & 59 & 11 & 150 & 78 & & & & & & & \\
\hline ASA_1014 & A4SJR9 & Pnp & Polyribonucleotide & 7.94 & 1.33 & 15 & 14 & 17 & 16 & $1.55 E-89$ & $6.02 \mathrm{E}-126$ & y & y & $\mathrm{n}$ & $\mathrm{n}$ & PF03726 \\
\hline & & & nucleotıdyltransterase & 3.42 & 0.52 & 23 & 1 & 36 & 17 & & & & & & & PF13014 \\
\hline & & & & & & & & & & & & & & & & PF07650 \\
\hline ASA_1826 & A4SLYO & $\mathrm{HtpG}$ & Chaperone protein HtpG & 2.80 & 7.78 & 18 & 14 & 24 & 21 & 7.44E-102 & $2.58 \mathrm{E}-181$ & $\mathrm{n}$ & y & $n$ & $\mathrm{n}$ & - \\
\hline & & & & 5.40 & 4.83 & 27 & 3 & 44 & 1 & & & & & & & \\
\hline ASA_2347 & A4SNC4 & MdeA & Methionine gamma-lyase & 1.98 & 0.35 & 10 & 8 & 8 & 8 & $1.14 \mathrm{E}-68$ & $2.52 \mathrm{E}-51$ & $\mathrm{n}$ & y & $n$ & $\mathrm{n}$ & PF00155 \\
\hline & & & & 1.45 & 0.80 & 15 & 5 & 26 & 24 & & & & & & & PF00266 \\
\hline ASA_1990 & A4SMD9 & PepN & Aminopeptidase N & 5.81 & 4.67 & 5 & 4 & 3 & 4 & $1.14 \mathrm{E}-14$ & $1.00 \mathrm{E}-13$ & $\mathrm{n}$ & y & $n$ & $\mathrm{n}$ & PF11940 \\
\hline & & & & 4.97 & 4.37 & 6 & 0 & 6 & 1 & & & & & & & PF01433 \\
\hline ASA_4301 & G7D0H6 & OpdA & Oligopeptidase A & 4.21 & 0.00 & 3 & 3 & 2 & 4 & $1.61 \mathrm{E}-08$ & $2.78 \mathrm{E}-08$ & y & y & $n$ & $n$ & PF01432 \\
\hline & & & & 3.33 & 2.12 & 3 & 0 & 3 & 0 & & & & & & & \\
\hline Without any & signal for & secretic & but having homologues $\mathrm{T} 3$ & creted & ther bacte & eria & & & & & & & & & & \\
\hline ASA_P5G088 & A4SUI8 & - & $\alpha / \beta$ hydrolase & 2.50 & 1.81 & 9 & 6 & 5 & 6 & $2.08 \mathrm{E}-56$ & 8.03E-19 & n (0.36) & $\mathrm{n}$ & $n$ & $\mathrm{n}$ & PF12697 \\
\hline & & & & 2.16 & -2.05 & 12 & 3 & 12 & 10 & & & & & & & PF12695 \\
\hline & & & & & & & & & & & & & & & & PF02129 \\
\hline & & & & & & & & & & & & & & & & PF00561 \\
\hline & & & & & & & & & & & & & & & & PF00326 \\
\hline & & & & & & & & & & & & & & & & PF12146 \\
\hline & & & & & & & & & & & & & & & & PF01738 \\
\hline & & & & & & & & & & & & & & & & PF08840PF07859 \\
\hline ASA_3402 & A4SR55 & Pta & Phosphate acetyltransferase & 7.13 & 1.42 & 9 & 7 & 4 & 3 & $2.98 \mathrm{E}-87$ & $5.28 \mathrm{E}-66$ & $\mathrm{n}$ & $\mathrm{n}$ & $\mathrm{n}$ & $\mathrm{n}$ & PF01515 \\
\hline & & & & 3.55 & -0.39 & 8 & 0 & 8 & 2 & & & & & & & \\
\hline
\end{tabular}


Table 2 Oversecreted proteins by $A$. salmonicida wt strain (Continued)

\begin{tabular}{|c|c|c|c|c|c|c|c|c|c|c|c|c|c|c|c|c|}
\hline \multirow[t]{2}{*}{$\overline{\text { ASA_4119 }}$} & \multirow[t]{2}{*}{ A4ST37 } & \multirow{2}{*}{$\begin{array}{l}\text { TypA } \\
\text { (BipA) }\end{array}$} & \multirow[t]{2}{*}{ GTP binding protein } & 2.12 & 2.24 & 14 & 12 & 19 & 18 & \multirow[t]{2}{*}{$2.93 \mathrm{E}-98$} & \multirow[t]{2}{*}{$1.52 \mathrm{E}-178$} & \multirow[t]{2}{*}{$n$} & \multirow[t]{2}{*}{$n$} & \multirow[t]{2}{*}{$\mathrm{n}$} & \multirow[t]{2}{*}{$\mathrm{n}$} & \multirow{2}{*}{$\begin{array}{l}\text { PF01926 } \\
\text { PF08477 }\end{array}$} \\
\hline & & & & 2.69 & 1.84 & 31 & 11 & 49 & 12 & & & & & & & \\
\hline \multirow[t]{2}{*}{ ASA_1768 } & \multirow[t]{2}{*}{ A4SLS5 } & \multirow[t]{2}{*}{ RpsA } & \multirow[t]{2}{*}{$30 \mathrm{~S}$ ribosomal protein $\mathrm{S} 1$} & 2.62 & 1.77 & 15 & 13 & 7 & 7 & \multirow[t]{2}{*}{$1.27 \mathrm{E}-135$} & \multirow[t]{2}{*}{ 1.40E-78 } & \multirow[t]{2}{*}{$\mathrm{n}$} & \multirow[t]{2}{*}{$n$} & \multirow[t]{2}{*}{$\mathrm{n}$} & \multirow[t]{2}{*}{$\mathrm{n}$} & \multirow[t]{2}{*}{-} \\
\hline & & & & 7.33 & 3.00 & 14 & 1 & 9 & 4 & & & & & & & \\
\hline \multirow[t]{2}{*}{ ASA_1202 } & \multirow[t]{2}{*}{ A4SK88 } & TktA & Transketolase 1 & 0.88 & 2.43 & 13 & 12 & 20 & 19 & $1.34 \mathrm{E}-82$ & 8.67E-175 & $\mathrm{n}$ & $\mathrm{n}$ & $n$ & $\mathrm{n}$ & PF00456 \\
\hline & & & & 2.67 & 1.22 & 14 & 13 & 32 & 8 & & & & & & & PF13292 \\
\hline ASA_0427 & A4SI83 & $A c n B$ & Aconitate hydratase 2 & 6.86 & 0.78 & 13 & 6 & 11 & 11 & $3.46 \mathrm{E}-52$ & 2.17E-117 & $\mathrm{n}$ & $n$ & $n$ & $n$ & PF00330 \\
\hline & & & & 5.65 & 1.77 & 13 & 0 & 20 & 10 & & & & & & & \\
\hline ASA_4076 & A4SSZ5 & RplX & 50 S ribosomal protein L24 & 6.01 & 1.86 & 5 & 4 & 9 & 9 & 4.94E-38 & 4.46E-89 & $\mathrm{n}$ & $n$ & $n$ & $n$ & PF00467 \\
\hline & & & & 1.11 & 1.00 & 5 & 0 & 37 & 23 & & & & & & & \\
\hline ASA_4087 & A4ST06 & RplC & $50 S$ ribosomal protein $\mathrm{L} 3$ & 2.24 & 5.67 & 6 & 5 & 6 & 6 & $1.14 \mathrm{E}-65$ & $5.13 \mathrm{E}-33$ & $\mathrm{n}$ & $\mathrm{n}$ & $n$ & $\mathrm{n}$ & PF00297 \\
\hline & & & & 3.03 & 2.24 & 26 & 12 & 16 & 4 & & & & & & & \\
\hline ASA_0684 & A4SIX5 & lles & Isoleucine-tRNA ligase & 5.92 & 2.17 & 7 & 7 & 13 & 13 & 4.17E-61 & $2.45 \mathrm{E}-50$ & $n$ & $n$ & $n$ & $n$ & PF00133 \\
\hline & & & & 3.14 & 0.39 & 11 & 0 & 18 & 10 & & & & & & & PF08264 \\
\hline & & & & & & & & & & & & & & & & PF09334 \\
\hline & & & & & & & & & & & & & & & & PF13603 \\
\hline & & & & & & & & & & & & & & & & PF01406 \\
\hline & & & & & & & & & & & & & & & & PF06827 \\
\hline ASA_1068 & A4SJW8 & LeuS & Leucine tRNA ligase & 4.86 & 1.11 & 3 & 3 & 2 & 3 & $7.59 \mathrm{E}-21$ & $1.04 \mathrm{E}-18$ & $\mathrm{n}$ & 0.91 & $n$ & $\mathrm{n}$ & PF13603 \\
\hline & & & & 3.17 & 4.42 & 2 & 0 & 2 & 0 & & & & & & & PF00133 \\
\hline & & & & & & & & & & & & & & & & PF09334 \\
\hline & & & & & & & & & & & & & & & & PF08264 \\
\hline ASA_0707 & A4SIZ7 & RpsF & 305 ribosomal protein $\mathrm{S} 6$ & 5.15 & 5.74 & 3 & 3 & 4 & 3 & $2.90 \mathrm{E}-24$ & $1.66 \mathrm{E}-10$ & $n$ & $n$ & $n$ & $\mathrm{n}$ & - \\
\hline & & & & -14.13 & 7.23 & 2 & 0 & 19 & 2 & & & & & & & \\
\hline ASA_1442 & A4SKW9 & WecB & UDP-N-acetylglucosamine 2- & 1.65 & 0.99 & 4 & 3 & 6 & 6 & $1.41 \mathrm{E}-30$ & $9.18 \mathrm{E}-24$ & $\mathrm{n}$ & $\mathrm{n}$ & $n$ & $\mathrm{n}$ & PF02350 \\
\hline & & & & 21.57 & 1.21 & 2 & 0 & 7 & 5 & & & & & & & \\
\hline With a sig & I for secre & tion by th & Sec-dependent pathway & & & & & & & & & & & & & \\
\hline ASA_1267 & A4SKF2 & OmpAl & Outer membrane protein $\mathrm{Al}$ & 7.22 & 6.94 & 8 & 5 & 11 & 6 & 9.60E-91 & 1.27E-145 & $\mathrm{n}$ & $n$ & y & $\mathrm{n}$ & - \\
\hline & & & & 1.02 & 3.43 & 12 & 0 & 37 & 0 & & & & & & & \\
\hline ASA_1544 & A4SL60 & OmpK40 & Outer membrane protein $\mathrm{K} 40$ & 5.80 & 5.70 & 8 & 8 & 7 & 6 & $4.58 \mathrm{E}-23$ & $7.69 \mathrm{E}-85$ & $n$ & $n$ & y & $\mathrm{n}$ & - \\
\hline & & & & 2.32 & 6.93 & 10 & 1 & 16 & 0 & & & & & & & \\
\hline ASA_3619 & A4SRQ8 & - & Hypothetical ABC-type Fe3 + & 5.27 & 4.08 & 3 & 2 & 6 & 5 & 8.50E-36 & 4.00E-16 & $\mathrm{n}$ & $\mathrm{n}$ & y & $\mathrm{n}$ & - \\
\hline & & & $\begin{array}{l}\text {-hydroxamate transport } \\
\text { system component }\end{array}$ & 4.71 & 5.77 & 5 & 0 & 21 & 3 & & & & & & & \\
\hline
\end{tabular}


Table 2 Oversecreted proteins by $\boldsymbol{A}$. salmonicida wt strain (Continued)

\begin{tabular}{|c|c|c|c|c|c|c|c|c|c|c|c|c|c|c|c|c|}
\hline \multirow[t]{2}{*}{ ASA_0330 } & $\mathrm{A} 4 \mathrm{SHZ1}$ & DegQ & Serine protease & 1.97 & 0.00 & 5 & 5 & 2 & 2 & $3.03 \mathrm{E}-43$ & $4.23 \mathrm{E}-69$ & $n$ & $\mathrm{n}$ & $y$ & $n$ & PF13180 \\
\hline & & & & 3.24 & 2.59 & 7 & 5 & 3 & 0 & & & & & & & PF00089 \\
\hline \multirow[t]{2}{*}{ ASA_0716 } & A4SJ06 & - & Insulinase, peptidase M16 & 2.61 & 0.53 & 16 & 11 & 11 & 11 & $6.18 \mathrm{E}-98$ & $6.71 \mathrm{E}-125$ & $n$ & $\mathrm{n}$ & y & $n$ & PF05193 \\
\hline & & & & 4.55 & 1.28 & 22 & 3 & 12 & 9 & & & & & & & PF00675 \\
\hline \multirow[t]{2}{*}{ ASA_0852 } & A4SJC4 & - & Hypothetical outer & 4.92 & 6.39 & 4 & 1 & 3 & 3 & $9.71 \mathrm{E}-08$ & $5.69 \mathrm{E}-56$ & $n$ & $\mathrm{n}$ & y & $n$ & - \\
\hline & & & membrane IIpoprotein & 20.61 & 4.48 & 7 & 0 & 10 & 0 & & & & & & & \\
\hline
\end{tabular}

The table shows fold changes for GP and SP in SNs (Log base 2 [wt/mut]) for PMSS and LFQ values, unique peptides, MS/MS Counts, PEP values, prediction for T3-effectors (Modlab and Effective) and secretion by alternative systems (SignalP and TatP), and the presence of eukaryotic domains in the protein. 
ASA_P5G088 in V. parahaemolyticus (35\% and 38\% of similarity with VP1677 and VP1678) were T3 secreted [58].

Ten cytoplasmic proteins were more abundant in wt vs $\Delta a s c V$ mutant $\mathrm{SNs}$, did not have any predicted signal for a secretion system and were not characterized as T3SS effectors in other bacteria (Table 2). TypA (or BipA) is a GTPase that was associated to virulence $[59,60]$ through regulation of the T3SS $[61,62]$. Interestingly, even though the TypA N-terminal part does not contain a predicted signal for $\mathrm{T} 3$ secretion, it shares three conserved motifs with the N-terminal part of EF-G and EF-Tu. Unclearly, ribosomal protein $30 \mathrm{~S} \mathrm{S1,} \mathrm{30S} \mathrm{S6,}$ 50 S L24 and L3, IleS, LeuS, Tkt, AcnB, and WecB were more abundant in wt SNs. All of these components were discovered to be associated to the A. salmonicida surfacome and in the secretome of other bacteria (refer to the Additional file 8 of the Part 1 of this work, "The Aeromonas salmonicida subsp. salmonicida exoproteome: global analysis, moonlighting proteins and putative antigens for vaccination against furunculosis" for details). AcnB and WecB have homologous proteins that have been associated to the virulence in other bacteria (Additional file 5).

Six proteins with a predicted $\mathrm{T} 1$ peptide signal were systematically found either in higher amounts or only in wt SNs compared to the $\triangle a s c V$ mutant (Table 2). That was the case for OmpAI (ASA_1267) and OmpK40 (ASA_1544), which were linked to virulence in Aeromonas and other bacteria (Additional file 5). The presence of these OM proteins in SNs was not an artefact given that OmpAII (ASA_1266) was produced just as much in pellets as OmpAI but was never detected in SNs (Additional file 1). The periplasmic trypsin-like serine protease DegQ (ASA_0330), the insulinase ASA_0716 (zinc-dependent peptidase M16), the putative OM lipoprotein ASA_0852, and the putative $\mathrm{ABC}$-type $\mathrm{Fe} 3+$-hydroxamate transport system component ASA_3619 were also increased in wt SNs, and such proteins have also been related to virulence in other bacteria (Additional file 5). Interestingly, A. hydrophila homologues of ASA_0852 and ASA_3619 were found in all toxic extracellular product fractions of the bacterium [63].

\section{Analysis of previously-described and newly detected putative virulence factors}

Besides the T3SS, other virulence factors of $A$. salmonicida have been characterized (or predicted) in the literature, and certain conserved proteins are homologous to virulent toxins, adhesins and enzymes identified in other bacteria (Table 3, Additional file 5). We identified the tetragonal surface virulence array protein VapA, aerolysin AerA, hemolysin AerB, esterase SatA, extracellular phospholipase PlaA1, phospholipase PlaC, the metalloprotease/mucinase, serine protease Ahe2, chitin/ N-acetylglucosamine-binding protein (ASA_0604), extracellular nuclease (ASA_1199), enolase (ASA_3475), and outer membrane endopeptidase PepO. Our results showed that all these toxins and enzymes were secreted as much as or more as in the extremely low-virulent $\Delta$ asc $V$ mutant (Figure 5, Table 3 and Additional file 2) and they highlighted that an intact T3SS is primordial to initiate the disease. This observation is supported by studies demonstrating that the deletion of T3SS genes completely abolishes the virulence [2,3,13-16,24,64].

Our proteomic study also characterized, the secretion in SNs of other putative virulent toxins, adhesins and enzymes conserved among Aeromonas sp. for the first time (Table 3, Additional file 5), in decreasing order of quantity in SNs (Additional file 2): the large RTX (repeats in toxin) exoprotein Asx (ASA_0826), a microbial collagenase (ASA_3723), an unknown protein ASA_2541 that could be co-expressed/secreted with Ahe2, the nuclease NucH (ASA_2206), a leucine aminopeptidase (ASA_3073), two large unknown proteins with a Ig-like domain (homologues to pRA1_0073 in IncA/C plasmids and ASA_P4G163), chitinases CdxA, Chi2 (ASA_2142) and ChiB (ASA_3320), the solute receptor TAXI (TRAP-associated extracytoplasmic immunogenic) of a TRAP transporter (ASA_3982), the immune inhibitor A metalloprotease PrtV (ASA_0849), the metalloprotease LasA, a LysM domaincontaining protein (ASA_1027), the hypothetical GlyGlyCTERM protein ASA_1998, the micrococcal nuclease (SNase-like) ASA_P4G031, the azurin, and the Type I pilus subunit FimD. All of these proteins were as much as or more secreted in mutant SNs (Table 3 and Additional file 2), highlighting once again that an intact T3SS is primordial to initiate the disease. The putative hemolysin ASA_1523 was only detected in pellets and in higher quantity in the mutant strain.

In the genome of $A$. salmonicida A449, Zonular Occludens Toxins (Zot, ASA_2003 and ASA_2015), elastase AhpB and toxic extracellular endopeptidase AsaP1 genes are impaired by deletions and insertion elements. According to these observations, we did not detect any polypeptides for these proteins in our MS experiments, suggesting that they would be also disrupted in our A. salmonicida strain. Furthermore, the insecticidal cytolytic delta-endotoxin (ASA_2128), putative RTX toxins (ASA_0127, ASA_1674 and ASA_1675), a secreted metalloprotease (ASA_1723) and the pullulanase PulA were not identified, and their expression might be induced in the host. Finally, 15 prophage proteins were identified in pellets $(12 \%$ of prophage genes detected in the genome of the reference strain A449) and only one (ASA_2013) was detected in SNs, but without any significant differences between the wt and mutant strains. 
Table 3 Other characterized or putative virulence factors of A. salmonicida

\begin{tabular}{|c|c|c|c|c|c|c|c|c|c|c|c|c|c|c|c|c|}
\hline \multirow[t]{2}{*}{ Locus } & \multirow[t]{2}{*}{ Uniprot } & \multirow[t]{2}{*}{ Name } & \multirow[t]{2}{*}{ Description } & \multicolumn{2}{|c|}{$\begin{array}{l}\text { Fold change in SNs wt/ } \\
\left.\text { mut [PMSS] }]^{1} \text { and [LFQ }\right]^{2}\end{array}$} & \multicolumn{4}{|c|}{$\begin{array}{l}\text { [Unique peptides] }]^{3} \\
\text { and [MS/MS Count] }]^{4}\end{array}$} & \multirow[t]{2}{*}{ PEP GP } & \multirow[t]{2}{*}{ PEP SP } & \multirow[t]{2}{*}{$\begin{array}{l}\text { Modlab } \\
(>0.4)\end{array}$} & \multirow[t]{2}{*}{$\begin{array}{l}\text { Effective } \\
(>0.95)\end{array}$} & \multirow[t]{2}{*}{ SignalP } & \multirow[t]{2}{*}{ TatP } & \multirow[t]{2}{*}{$\begin{array}{l}\text { Eukaryotic } \\
\text { domain }\end{array}$} \\
\hline & & & & $\begin{array}{l}\log _{2} \\
\text { (wt/mut) GP }\end{array}$ & $\begin{array}{l}\log _{2} \\
\text { (wt/mut) SP }\end{array}$ & $\begin{array}{l}\text { wt } \\
\text { GP }\end{array}$ & $\begin{array}{l}\text { mut } \\
\text { GP }\end{array}$ & $\begin{array}{l}\text { wt } \\
\text { SP }\end{array}$ & $\begin{array}{l}\text { mut } \\
\text { SP }\end{array}$ & & & & & & & \\
\hline \multicolumn{17}{|c|}{ Other characterized virulence factors } \\
\hline \multirow[t]{2}{*}{ ASA_1438 } & \multirow[t]{2}{*}{ A4SKW5 } & \multirow[t]{2}{*}{ VapA } & \multirow{2}{*}{$\begin{array}{l}\text { Tetragonal surface virulence array } \\
\text { protein }\end{array}$} & $-3.18^{1}$ & -1.66 & $35^{3}$ & 42 & 39 & 40 & \multirow[t]{2}{*}{$0.00 \mathrm{E}+00$} & \multirow[t]{2}{*}{$0.00 E+00$} & \multirow[t]{2}{*}{$\mathrm{n}$} & \multirow[t]{2}{*}{$n$} & \multirow[t]{2}{*}{ y } & \multirow[t]{2}{*}{$n$} & \multirow[t]{2}{*}{-} \\
\hline & & & & $-7.09^{2}$ & -4.02 & $284^{4}$ & 2096 & 1203 & 3044 & & & & & & & \\
\hline \multirow[t]{2}{*}{ ASA_3906 } & A4SSI7 & AerA & Aerolysin A & -2.43 & -0.69 & 18 & 28 & 27 & 28 & $7.56 \mathrm{E}-292$ & $0.00 \mathrm{E}+00$ & $\mathrm{n}$ & $\mathrm{n}$ & y & $\mathrm{n}$ & PF03318 \\
\hline & & & & -6.58 & -0.85 & 79 & 351 & 358 & 560 & & & & & & & \\
\hline ASA_2854 & A4SPP5 & AerB & Aerolysin B & -2.28 & -0.20 & 24 & 25 & 33 & 33 & $7.45 \mathrm{E}-255$ & $0.00 E+00$ & $\mathrm{n}$ & $n$ & y & $n$ & PF00652 \\
\hline & & & & -3.20 & 0.28 & 25 & 161 & 259 & 284 & & & & & & & \\
\hline ASA_0509 & A4SIF4 & SatA & Glycero-phospholipid-cholesterol & -1.54 & -0.89 & 16 & 15 & 24 & 24 & $2.62 \mathrm{E}-221$ & $0.00 E+00$ & $n$ & $n$ & y & $\mathrm{n}$ & \\
\hline & & & & -5.08 & -2.95 & 42 & 110 & 393 & 669 & & & & & & & PF00657 \\
\hline & & & & & & & & & & & & & & & & PF13472 \\
\hline ASA_4288 & A4STJO & PlaA1 & Phospholipase A1 & -0.14 & 0.21 & 22 & 23 & 24 & 23 & $0.00 \mathrm{E}+00$ & $0.00 \mathrm{E}+00$ & $n$ & $n$ & $n$ & $n$ & - \\
\hline & & & & -2.66 & -1.87 & 31 & 39 & 121 & 119 & & & & & & & \\
\hline ASA_0635 & A4SIS6 & $\mathrm{PlaC}$ & Phospholipase C & -4.90 & -6.49 & 2 & 5 & 8 & 10 & $2.22 \mathrm{E}-14$ & 4.03E-81 & $\mathrm{n}$ & $\mathrm{n}$ & y & $n$ & PF03372 \\
\hline & & & & -6.86 & -2.01 & 0 & 5 & 4 & 20 & & & & & & & \\
\hline ASA_3321 & A4SQY1 & TagA & Metalloprotease/mucinase ToxR- & -2.28 & -0.92 & 30 & 31 & 38 & 38 & 5.47E-206 & $0.00 \mathrm{E}+00$ & $n$ & $n$ & y & $n$ & - \\
\hline & & & & -6.12 & -2.38 & 30 & 137 & 230 & 406 & & & & & & & \\
\hline ASA_2540 & A4SNU7 & Ahe2 & Serine protease & -1.91 & -0.86 & 31 & 34 & 49 & 49 & $0.00 \mathrm{E}+00$ & $0.00 \mathrm{E}+00$ & $n$ & $n$ & y & $n$ & PF01483 \\
\hline & & & & -5.65 & -2.51 & 529 & 1363 & 4391 & 6633 & & & & & & & \\
\hline ASA_0604 & A4SIP8 & ChiY & Chitin-binding protein & -3.24 & -1.03 & 15 & 19 & 22 & 24 & $2.64 \mathrm{E}-275$ & $0.00 \mathrm{E}+00$ & $n$ & $n$ & $n$ & $n$ & PF03067 \\
\hline & & & & -6.29 & -1.94 & 17 & 124 & 309 & 548 & & & & & & & \\
\hline ASA_1199 & A4SK85 & Nuc & Extracellular desoxyribonuclease & NV & -2.61 & 0 & 0 & 9 & 9 & NV & 4.65E-86 & $n$ & $n$ & y & $n$ & PF04231 \\
\hline & & & & & -3.19 & 0 & 0 & 6 & 20 & & & & & & & \\
\hline ASA_3475 & A4SRC1 & Eno & Enolase & 0.85 & -0.98 & 15 & 17 & 17 & 20 & $6.58 \mathrm{E}-271$ & $0.00 E+00$ & $n$ & $n$ & $n$ & $n$ & PF00113 \\
\hline & & & & 0.44 & -1.70 & 50 & 35 & 34 & 80 & & & & & & & PF03952 \\
\hline & & & & & & & & & & & & & & & & PF07476 \\
\hline ASA_3132 & A4SQF4 & PepO & Peptidase M13 & NV & NV & NV & NV & NV & NV & NV & NV & $n$ & $n$ & y & $n$ & PF05649 \\
\hline & & & & & & & & & & & & & & & & PF01431 \\
\hline
\end{tabular}


Table 3 Other characterized or putative virulence factors of $\boldsymbol{A}$. salmonicida (Continued)

\begin{tabular}{|c|c|c|c|c|c|c|c|c|c|c|c|c|c|c|c|c|}
\hline \multicolumn{17}{|c|}{ Putative virulence factors } \\
\hline \multirow[t]{2}{*}{ ASA_0826 } & \multirow[t]{2}{*}{ A4SJA3 } & \multirow[t]{2}{*}{ Asx } & \multirow[t]{2}{*}{ RTX large exoprotein } & -0.50 & -0.22 & 92 & 90 & 106 & 107 & \multirow[t]{2}{*}{$0.00 E+00$} & \multirow[t]{2}{*}{$0.00 E+00$} & \multirow[t]{2}{*}{$\mathrm{n}$} & \multirow[t]{2}{*}{$n$} & \multirow[t]{2}{*}{$n$} & \multirow[t]{2}{*}{$\mathrm{n}$} & \multirow[t]{2}{*}{ PF00092 } \\
\hline & & & & -1.11 & -1.15 & 1372 & 1991 & 3830 & 4248 & & & & & & & \\
\hline \multirow[t]{2}{*}{ ASA_3723 } & \multirow[t]{2}{*}{ A4SS12 } & \multirow[t]{2}{*}{-} & \multirow[t]{2}{*}{ Microbial collagenase } & -0.83 & -0.67 & 66 & 64 & 80 & 80 & \multirow[t]{2}{*}{$0.00 E+00$} & \multirow[t]{2}{*}{$0.00 E+00$} & \multirow[t]{2}{*}{$\mathrm{n}$} & \multirow[t]{2}{*}{$n$} & \multirow[t]{2}{*}{ y } & \multirow[t]{2}{*}{$n$} & \multirow[t]{2}{*}{-} \\
\hline & & & & -0.96 & -0.90 & 529 & 974 & 3304 & 4967 & & & & & & & \\
\hline \multirow[t]{2}{*}{ ASA_2541 } & \multirow[t]{2}{*}{ A4SNU8 } & \multirow[t]{2}{*}{-} & Unknown & -2.20 & -1.01 & 11 & 11 & 13 & 14 & 1.91E-144 & $0.00 \mathrm{E}+00$ & $n$ & $n$ & y & $\mathrm{n}$ & - \\
\hline & & & & -5.88 & -3.83 & 121 & 582 & 1571 & 2701 & & & & & & & \\
\hline ASA_2206 & A4SMZ6 & $\mathrm{NuCH}$ & Nuclease & -2.09 & -0.69 & 39 & 43 & 41 & 41 & $0.00 E+00$ & $0.00 E+00$ & $n$ & $n$ & y & $\mathrm{n}$ & PF03160 \\
\hline & & & & -5.38 & -1.48 & 75 & 289 & 215 & 345 & & & & & & & PF03372 \\
\hline ASA_3073 & A4SQ99 & - & Leucine aminopeptidase & -2.31 & -0.78 & 13 & 14 & 17 & 17 & 1.39E-191 & $0.00 E+00$ & $n$ & $n$ & y & $\mathrm{n}$ & PF04389 \\
\hline & & & & -5.13 & -2.04 & 40 & 157 & 1074 & 1519 & & & & & & & PF01546 \\
\hline pRA1_0073 & C6GA30 & - & Group 3 lg-like domain protein & -0.80 & -0.34 & 43 & 42 & 85 & 85 & $0.00 \mathrm{E}+00$ & $0.00 E+00$ & $n$ & $n$ & y & $n$ & - \\
\hline & & & & -1.30 & -1.33 & 67 & 108 & 859 & 992 & & & & & & & \\
\hline ASA_P4G163 & A4SU89 & - & Group 3 lg-like domain & -0.59 & -0.36 & 10 & 10 & 16 & 16 & $1.01 \mathrm{E}-102$ & $0.00 E+00$ & $\mathrm{n}$ & $n$ & y & $n$ & - \\
\hline & & & & -1.65 & -1.21 & 19 & 36 & 171 & 207 & & & & & & & \\
\hline ASA_0873 & A4SJD6 & $C d x A$ & Chitinase & -1.50 & -0.76 & 27 & 29 & 50 & 51 & $0.00 E+00$ & $0.00 E+00$ & $n$ & $n$ & y & y & PF00704 \\
\hline & & & & -2.75 & -1.31 & 48 & 165 & 305 & 553 & & & & & & & PF02839 \\
\hline ASA_2142 & A4SMT5 & Chi2 & Chitinase & -4.10 & -2.39 & 11 & 17 & 22 & 25 & $5.49 \mathrm{E}-126$ & $0.00 E+00$ & $n$ & $n$ & y & $n$ & PF00182 \\
\hline & & & & -7.15 & -2.91 & 5 & 86 & 56 & 235 & & & & & & & PF02839 \\
\hline ASA_3320 & A4SQY0 & ChiB & Chitinase & -2.59 & -1.07 & 13 & 13 & 27 & 27 & 4.47E-159 & $0.00 E+00$ & $n$ & $n$ & y & $n$ & PF00182 \\
\hline & & & & -4.79 & -2.82 & 19 & 94 & 180 & 370 & & & & & & & PF02839 \\
\hline ASA_3982 & A4SSR0 & Taxi & TRAP-associated extracytoplasmic & 0.51 & -1.50 & 11 & 9 & 16 & 18 & 4.95E-131 & $0.00 E+00$ & $n$ & $n$ & y & $\mathrm{n}$ & PF09084 \\
\hline & & & Imn & 0.22 & 0.20 & 18 & 18 & 63 & 127 & & & & & & & \\
\hline ASA_0849 & G7CXH6 & PrtV & immune inhibitor $\mathrm{A}$ & -0.16 & 1.19 & 16 & 17 & 29 & 29 & $1.92 \mathrm{E}-129$ & $0.00 E+00$ & y & $n$ & $n$ & $n$ & - \\
\hline & & & & -2.54 & 0.67 & 17 & 28 & 169 & 82 & & & & & & & \\
\hline ASA_1287 & A4SKH1 & LasA & Metalloprotease & -2.82 & -1.45 & 10 & 13 & 13 & 13 & $2.90 \mathrm{E}-123$ & $0.00 E+00$ & $n$ & y & $n$ & $n$ & PF01551 \\
\hline & & & & -6.19 & -4.03 & 16 & 81 & 146 & 349 & & & & & & & \\
\hline ASA_1027 & A4SJT2 & - & LysM domain-containing protein & -0.57 & 1.00 & 10 & 10 & 12 & 12 & $1.92 \mathrm{E}-87$ & 4.24E-187 & $\mathrm{n}$ & $\mathrm{n}$ & y & $\mathrm{n}$ & PF01476 \\
\hline & & & & -1.71 & 0.46 & 20 & 32 & 135 & 87 & & & & & & & \\
\hline ASA_1998 & A4SME7 & - & GlyGly-CTERM protein & -1.80 & -1.20 & 21 & 24 & 29 & 29 & 3.33E-303 & $0.00 \mathrm{E}+00$ & $n$ & $n$ & y & $n$ & - \\
\hline
\end{tabular}


Table 3 Other characterized or putative virulence factors of $\boldsymbol{A}$. salmonicida (Continued)

\begin{tabular}{|c|c|c|c|c|c|c|c|c|c|c|c|c|c|c|c|c|}
\hline & & & & -2.17 & -1.01 & 26 & 91 & 115 & 226 & & & & & & & \\
\hline \multirow[t]{2}{*}{ ASA_1199 } & A4SK85 & - & Extracellular desoxyribonuclease & NV & -2.61 & NV & NV & 9 & 9 & NV & 4.65E-86 & $n$ & $\mathrm{n}$ & y & $\mathrm{n}$ & PF04231 \\
\hline & & & & & -3.19 & & & 6 & 20 & & & & & & & \\
\hline \multirow[t]{2}{*}{ ASA_P4G031 } & A4STW2 & - & Micrococcal nuclease (SNase-like) & -0.45 & -5.77 & 3 & 3 & 6 & 7 & $1.24 \mathrm{E}-04$ & $9.28 \mathrm{E}-20$ & $\mathrm{n}$ & y & $\mathrm{n}$ & $n$ & PF00565 \\
\hline & & & & -0.51 & -3.82 & 3 & 4 & 3 & 29 & & & & & & & \\
\hline
\end{tabular}

The table shows fold changes for GP and SP in SNs (Log base 2 [wt/mut]) for PMSS and LFQ values, unique peptides, MS/MS Counts, PEP values, prediction for T3-effectors (Modlab and Effective) and secretion by alternative systems (SignalP and TatP), and the presence of eukaryotic domains in the protein.

NV: No value, not detected. 


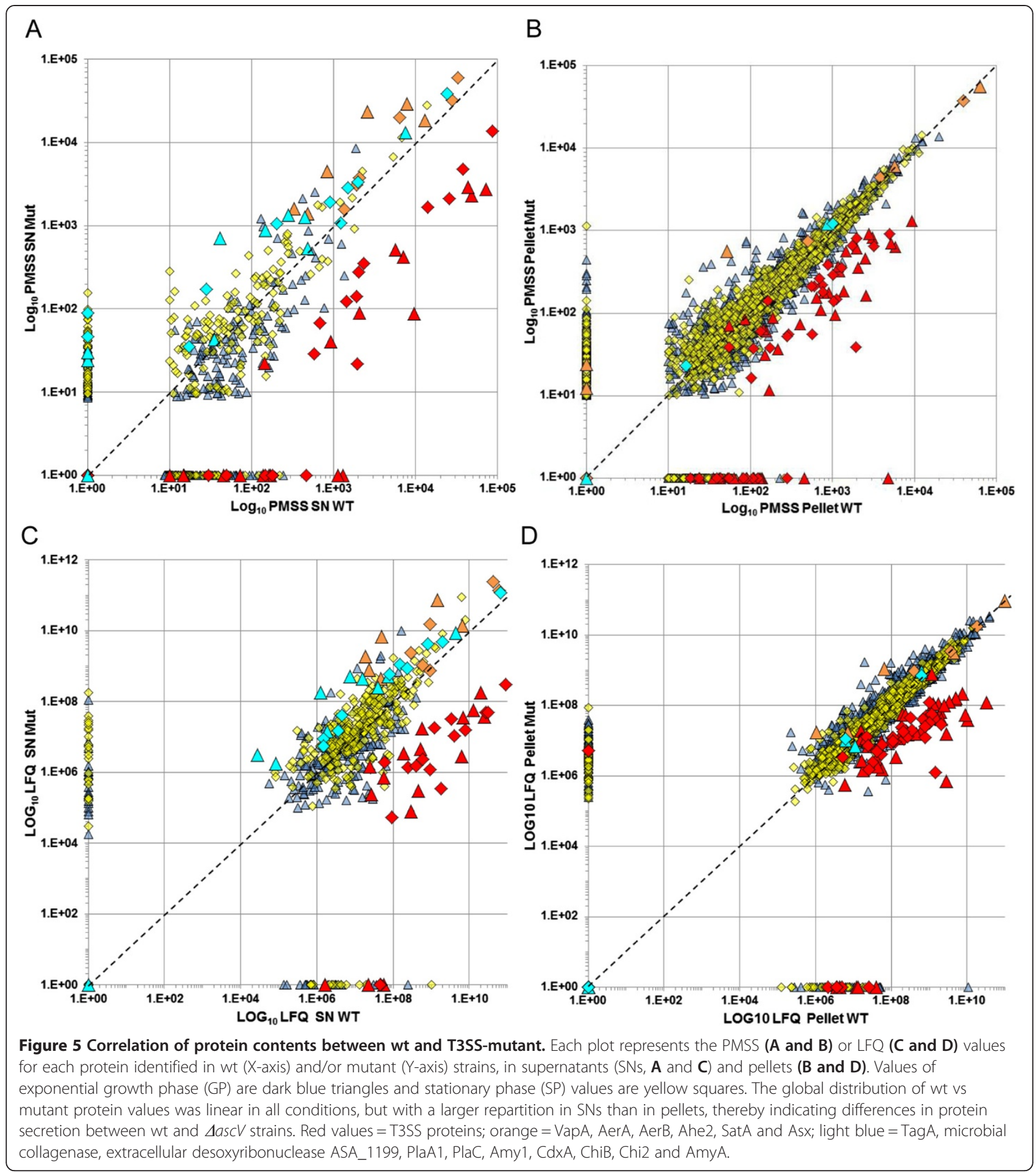

\section{Conclusions}

The comparison by high-throughput proteomics of $A$. salmonicida secretomes from wt and T3SS-deficient strains is a powerful method that gave us the opportunity (i) to characterize the full in vitro repertoire of T3SS effectors represented mainly by AopH, Ati2, AexT, AopP, AopO, AopN and ExsE, (ii) to identify new putative virulence factors that are secreted in the extracellular medium or might be translocated into the host cell by the T3SS or alternative mechanisms, and (iii) to confirm that $A$. salmonicida secreted toxins, adhesins and enzymes that have been described until now and are additionally found in this study are secreted to a higher extent in the extremely low-virulent $\triangle a s c V$ mutant. 
Our results also clearly show that the deletion of one gene ( $a s c V$ in this study) can induce the down-regulation of several other genes (only associated to the T3SS in our study), not necessary transcriptionally linked in the same operon. To respect the molecular Koch's postulates, we can conclude from this study that each work investigating phenotypic characters by site-directed mutagenesis should ideally be completed by a larger analysis studying the impact of the mutation over the global gene expression.

Due to the fact that we studied in vitro secretomes, T3SS effectors that we have found might be considered as the first line of weapons that A. salmonicida uses to invade fish and initiate the disease. Inside the salmonid, bacteria might induce the expression of genes specific to the A. salmonicida species and present in genomic islands (such as the cluster of genes [ASA_1049 to ASA_1052] homologous to the Vibrio Seventh pandemic Island-I [VSP-I]) that might be necessary to survive in new environments [65]. Interestingly, T3SS effectors predicted by bioinformatics are two times more abundant in genomic regions specific to A. salmonicida (15\% of specific genes) than in genetic regions common to all Aeromonas species (8\% of common genes). Further proteomics studies will be necessary in order to confirm the in vivo $A$. salmonicida secretome.

\section{Methods}

Cell culture and preparation of bacterial supernatants and pellets for LC-MS/MS

Aeromonas salmonicida wt and $\Delta a s c V$ mutant strains used in this study were characterized in a previous work [15]. To get $A$. salmonicida wt cultures into a maximum T3SS activation state, we used JF2267 strain which was freshly reisolated from an experimentally infected dead fish (JF5054). This re-isolated strain was highly virulent, since intraperitoneal inoculation of only $500 \mathrm{cfu}$ per fish was sufficient to induce 70 to $80 \%$ of mortality in challenge assays [22]. The $\Delta a s c V$ mutant strain JF2747 is considered to have extremely low-virulence because $10^{5}$ cfu/fish induced no mortality [15], and $10^{8} \mathrm{cfu} /$ fish induced a weak mortality of only $20 \%$.

To precipitate and concentrate proteins from the supernatant of wt and $\Delta a s c V A$. salmonicida, $50 \mathrm{ml}$ of TSB medium were inoculated with $10^{9}$ bacteria and cultivated at $18^{\circ} \mathrm{C}$ under shaking $(160 \mathrm{rpm})$ in the presence of protease inhibitors (Complete, Roche Diagnostics). The bacterial growth was stopped during the exponential phase of growth $\left(\mathrm{DO}_{600}=\sim 1.5\right)$ and the stationary phase $\left(\mathrm{DO}_{600}>2.0\right)$. Supernatants were separated from bacterial pellets by centrifugation $(6.000 \times \mathrm{g}, 10 \mathrm{~min}$, $4^{\circ} \mathrm{C}$ ) and filtration through a $0.22 \mu \mathrm{M}$ Acrodisc filter (low protein binding, PALL Life Sciences). The bacterial pellets were resuspended in $10 \mathrm{ml}$ of $\mathrm{PBS}$, and $250 \mu \mathrm{L}$ of these solutions were mixed with $250 \mu \mathrm{L}$ of
SDS loading buffer and heated at $100^{\circ} \mathrm{C}$ for $5 \mathrm{~min}$. To precipitate proteins from supernatants, $12.5 \mathrm{ml}$ of $100 \%$ ice-cold trichloroacetic acid were added to the solutions (20\% final concentration), then immediately vortexed and incubated overnight on ice. Supernatants were removed and brown protein pellets were suspended and washed several times by centrifugation in ice-cold 100\% acetone in $2 \mathrm{ml}$ Eppendorf tubes (low binding protein). Finally, the pellets were dried, diluted in $250 \mu \mathrm{L}$ of SDS loading buffer ( 200 times concentration) and heated at $100^{\circ} \mathrm{C}$ for $5 \mathrm{~min}$. Proteins were separated in non-adjacent wells (to avoid well to well contamination) on $15 \%$ acrylamide SDS-PAGE gels and stained with Coomassie. One run for each of the eight biological conditions (wt vs mutant, GP vs SP and SN vs pellet) was completely sliced from the stacking gel to the buffer front in 20 to 25 bands, and each band was cut into small $\left(\sim 1 \mathrm{~mm}^{3}\right)$ cubes for protein in-gel digestion and MS analysis, as described elsewhere [66,67]. Peptide sequencing was made on a LTQ Orbitrap XL mass spectrometer (ThermoFisher Scientific, Bremen; Germany) equipped with a Rheos Allegro nano flow system with AFM flow splitting (Flux Instruments, Reinach; Switzerland) and a nano electrospray ion source operated at a voltage of $1.7 \mathrm{kV}$. Peptide separation was performed on a Magic C18 column $(5 \mu \mathrm{m}, 100 \AA, 0.075 \times 70 \mathrm{~mm})$ using a flow rate of $\sim 400 \mathrm{~nL} / \mathrm{min}$ and a linear gradient of 5 to $40 \%$ acetonitrile in water $/ 0.1 \%(\mathrm{v} / \mathrm{v})$ formic acid during $60 \mathrm{~min}$.

The mass spectrometry proteomics data were deposited to the ProteomeXchange Consortium (http://proteomecentral. proteomexchange.org) via the PRIDE partner repository [68] with the dataset identifier PXD000429 and DOI 10.6019/ PXD000429.

\section{LC-MS/MS data interpretation}

LC-MS/MS data interpretation was made against the current UniProtKB database release (2012_06) of all known $A$. salmonicida protein sequences. Two methods of relative protein quantification were used. The peptidematching score summation (PMSS) is a label-free technique that assumes ideal scoring for proteins as the summative of the identification scores of their constituent peptides freed upon digestion. A higher score represents a more abundant protein [69]. The EasyProt search algorithm [70] was used for this, as described in [67]. The obtained mass spectrometric raw data were also analyzed with MaxQuant, version 1.2.2.5 [71], and its label-free quantitation (LFQ) algorithms [72] allowed quantitative comparisons. MaxQuant settings were as follows: Accepted false discovery rates at peptide, modified peptide and protein level were set at $1 \%$ using the reversed sequence database. Carbamidomethylation on Cys was set as a fixed modification. Oxidation of Met, acetylation on protein N-terminus, and phosphorylation on Set/Thr/Tyr 
were set as variable modifications with a precursor mass tolerance of $6 \mathrm{ppm}$ in the main search, while only oxidation and acetylation with a mass accuracy of $20 \mathrm{ppm}$ was used in the first search. Trypsin cleavage specificity was set at full with a maximum 2 missed cleavages and the allowance of up to three modifications per peptide of length between 6-25 amino acids. Fragment spectra were filtered to the 6 most intense peaks per $100 \mathrm{Da}$ mass windows and searched with a mass tolerance of $0.5 \mathrm{Da}$. Protein identifications were accepted with at least 2 razor and unique peptide identifications. For label free quantification (LFQ), at least 2 unmodified or acetylated protein $\mathrm{N}$ terminal peptides were required, and matching within a 2 minute time frame between samples was allowed. Only proteins with significant increased PMSS and LFQ values in GP and SP of wt vs mutant SNs were developed in the text.

\section{Bioinformatics analysis}

Detection of signal sequences for secretion was carried out using the SignalP 4.1 server (http://www.cbs.dtu.dk/ services/SignalP/) [73], TatP 1.0 server (http://www.cbs. dtu.dk/services/TatP/) [74] and the T3SS effector prediction softwares from Modlab ${ }^{\circ}$ (http://gecco.org.chemie. uni-frankfurt.de/T3SS_prediction/T3SS_prediction.html) [75] and EffectiveT3 (http://www.effectors.org/) [76]. The list of A. salmonicida $\mathrm{ABC}$ transporters was provided by $\mathrm{ABCdb}$ (https://www-abcdb.biotoul.fr/) [77] and prohage genes by PHAST (http://phast.wishartlab. com/index.html) [78].

\section{Additional files}

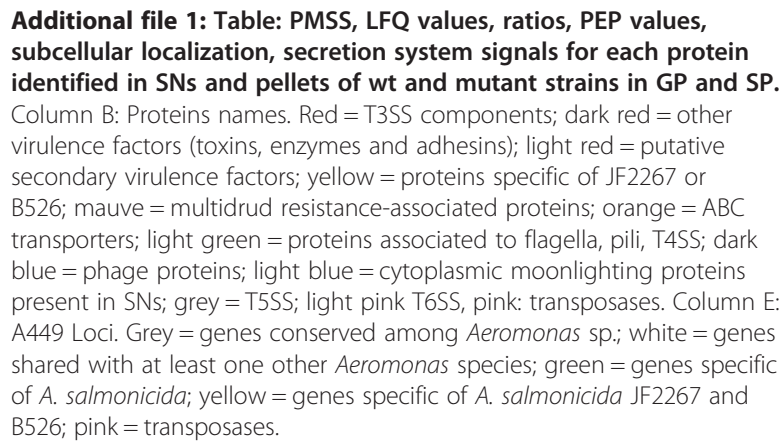

Additional file 2: Figure: most abundant proteins in A. salmonicida supernatants of wt and mutant strains in GP and SP. The diagram represents the most abundant proteins secreted by $A$. salmonicida (in decreasing order of PMSS values in wt SN during GP). Below the name of the protein circles represent T3SS components (red), other virulence factors (toxins, enzymes and adhesins) (pink), putative secondary virulence factors (yellow) and cytoplasmic proteins with putative moonlighting activity (green).

Additional file 3: Figure: most abundant proteins in $A$. salmonicida pellets of wt and mutant strains in GP and SP. The diagram represents the most abundant proteins detected in A. salmonicida pellets (in decreasing order of PMSS values in wt pellet during GP). Below the name of the protein circles represent T3SS components (red), other virulence factors (toxins, enzymes and adhesins) (pink), putative secondary virulence factors (yellow) and secreted cytoplasmic proteins with putative moonlighting activity (green).

Additional file 4: Figure: confirmation by western blotting of the difference in quantity observed between the pellets of the wt and the $\triangle a s c V$ mutant in the GP for AopD, AcrV and AexT.

Additional file 5: Table: $A$. salmonicida secreted proteins that have homologues in other bacteria with a putative role in virulence.

\section{Abbreviations}

APC: Antigen presenting cell; CTL: Cytotoxic T lymphocytes; GP: Exponential phase of growth; LFQ: Label-free quantitation; PMSS: Peptide-matching score summation; SN: Supernatant; SP: Stationary phase of growth; T3SS: Type-

three secretion system; wt: wild-type.

\section{Competing interests}

The authors have declared that no competing interests exist.

\section{Authors' contributions}

PVB conceived of the study, carried out the experiments, analyzed data from MS, performed bioinformatic analyses and drafted the manuscript. SB- $L$ and $\mathrm{MH}$ performed MS experiments and interpretation of MS data. JF helped to draft the manuscript. Authors read and approved the final manuscript.

\section{Acknowledgements}

This research was funded by the Swiss National Science Foundation grant no. 31003A-135808. We are especially grateful to Dr. Thomas Whali (Centre for Fish and Wildlife Health, Vetsuisse Faculty, University of Bern, Switzerland) for his rapid and thorough help with in vivo challenges. The authors are especially grateful to Dr Cedric Simillion (Department of Clinical Research, University of Bern, Switzerland) for his invaluable technical assistance.

\section{Author details}

${ }^{1}$ Institute of Veterinary Bacteriology, University of Bern, Länggassstrasse 122, Bern, Switzerland. ${ }^{2}$ Department of Clinical Research, University of Bern, P.O. Box 37, 3010, Bern, Switzerland.

Received: 5 June 2013 Accepted: 23 September 2013

Published: 27 September 2013

\section{References}

1. Janda JM, Abbott SL: The genus Aeromonas: taxonomy, pathogenicity, and infection. Clin Microbiol Rev 2010, 23:35-73.

2. Burr SE, Stuber K, Wahli T, Frey J: Evidence for a type III secretion system in Aeromonas salmonicida subsp. salmonicida. J Bacteriol 2002, 184:5966-5970.

3. Stuber K, Burr SE, Braun M, Wahli T, Frey J: Type III secretion genes in Aeromonas salmonicida subsp salmonicida are located on a large thermolabile virulence plasmid. J Clin Microbiol 2003, 41:3854-3856.

4. Noonan B, Trust TJ: The synthesis, secretion and role in virulence of the paracrystalline surface protein layers of Aeromonas salmonicida and A. hydrophila. FEMS Microbiol Let 1997, 154:1-7.

5. Dacanay A, Boyd JM, Fast MD, Knickle LC, Reith ME: Aeromonas salmonicida Type I pilus system contributes to host colonization but not invasion. Dis Aq Org 2010, 88:199-206.

6. Masada CL, LaPatra SE, Morton AW, Strom MS: An Aeromonas salmonicida type IV pilin is required for virulence in rainbow trout Oncorhynchus mykiss. Dis Aq Org 2002, 51:13-25.

7. Boyd JM, Dacanay A, Knickle LC, Touhami A, Brown LL, Jericho MH, Johnson SC, Reith M: Contribution of type IV pili to the virulence of Aeromonas salmonicida subsp salmonicida in Atlantic salmon (Salmo salar I.). Infect Immun 2008, 76:1445-1455.

8. Dacanay A, Johnson SC, Bjornsdottir R, Ebanks RO, Ross NW, Reith M, Singh RK, Hiu J, Brown LL: Molecular characterization and quantitative analysis of superoxide dismutases in virulent and avirulent strains of Aeromonas salmonicida subsp salmonicida. J Bact 2003, 185:4336-4344.

9. Vipond R, Bricknell IR, Durant E, Bowden TJ, Ellis AE, Smith M, Maclntyre S: Defined deletion mutants demonstrate that the major secreted toxins 
are not essential for the virulence of Aeromonas salmonicida. Infect Immun 1998, 66:1990-1998.

10. Lee KK, Ellis AE: Glycerophospholipid-cholesterol acyltransferase complexed with lipopolysaccharide (Lps) is a major lethal exotoxin and cytolysin of Aeromonas salmonicida - Lps stabilizes and enhances toxicity of the enzyme. J Bact 1990, 172:5382-5393.

11. Hirono I, Aoki T: Cloning and characterization of 3 hemolysin genes from Aeromonas salmonicida. Microb Pathogenesis 1993, 15:269-282.

12. Reith ME, Singh RK, Curtis B, Boyd JM, Bouevitch A, Kimball J, Munholland J, Murphy C, Sarty D, Williams J, et al: The genome of Aeromonas salmonicida subsp salmonicida A449: insights into the evolution of a fish pathogen. BMC Genomics 2008, 9:1-15.

13. Burr SE, Wahli T, Segner H, Pugovkin D, Frey J: Association of type III secretion genes with virulence of Aeromonas salmonicida subsp salmonicida. Dis Aq Org 2003, 57:167-171.

14. Dacanay A, Knickle L, Solanky KS, Boyd JM, Walter JA, Brown LL, Johnson SC, Reith M: Contribution of the type III secretion system (TTSS) to virulence of Aeromonas salmonicida subsp salmonicida. Microbiology - SGM 2006, 152:1847-1856.

15. Burr SE, Pugovkin D, Wahli T, Segner H, Frey J: Attenuated virulence of an Aeromonas salmonicida subsp salmonicida type III secretion mutant in a rainbow trout model. Microbiology - SGM 2005, 151:2111-2118.

16. Daher RK, Filion G, Tan SGE, Dallaire-Dufresne S, Paquet VE, Charette SJ: Alteration of virulence factors and rearrangement of pAsa5 plasmid caused by the growth of Aeromonas salmonicida in stressful conditions. Vet Microbiol 2011, 152:353-360.

17. Marlovits TC, Stebbins CE: Type III secretion systems shape up as they ship out. Curr Opin Microbiol 2010, 13:47-52.

18. Burr SE, Stuber K, Frey J: The ADP-ribosylating toxin, AexT, from Aeromonas salmonicida subsp salmonicida is translocated via a type III secretion pathway. J Bact 2003, 185:6583-6591.

19. Fehr D, Burr SE, Gibert M, d'Alayer J, Frey J, Popoff MR: Aeromonas exoenzyme T of Aeromonas salmonicida is a bifunctional protein that targets the host cytoskeleton. J Biol Chem 2007, 282:28843-28852.

20. Fehr D, Casanova C, Liverman A, Blazkova H, Orth K, Dobbelaere D, Frey J, Burr SE: AopP, a type III effector protein of Aeromonas salmonicida, inhibits the NF-kappa B signalling pathway. Microbiology 2006, 152:2809-2818.

21. Fast MD, Tse B, Boyd JM, Johnson SC: Mutations in the Aeromonas salmonicida subsp salmonicida type III secretion system affect Atlantic salmon leucocyte activation and downstream immune responses. Fish Shellfish Immun 2009, 27:721-728.

22. Vanden Bergh P, Burr SE, Benedicenti O, von Siebenthal B, Frey J, Wahli T: Antigens of the type-three secretion system of $A$. salmonicida subsp. salmonicida prevent protective immunity in rainbow trout. Vaccine: in press.

23. Broberg CA, Zhang LL, Gonzalez H, Laskowski-Arce MA, Orth K: A Vibrio effector protein is an inositol phosphatase and disrupts host cell membrane integrity. Science 2010, 329:1660-1662.

24. Crabill E, Karpisek A, Alfano JR: The Pseudomonas syringae HrpJ protein controls the secretion of type III translocator proteins and has a virulence role inside plant cells. Mol Microbio/ 2012, 85:225-238.

25. Archuleta TL, Du YQ, English CA, Lory S, Lesser C, Ohi MD, Ohi R, Spiller BW: The Chlamydia effector chlamydial outer protein $\mathrm{N}(\mathrm{CopN})$ sequesters tubulin and prevents microtubule assembly. J Biol Chem 2011, 286:33992-33998.

26. Nagamatsu K, Kuwae A, Konaka T, Nagai S, Yoshida S, Eguchi M, Watanabe M, Mimuro H, Koyasu S, Abe A: Bordetella evades the host immune system by inducing IL-10 through a type III effector, BopN. J Exp Med 2009, 206:3073-3088.

27. Day JB, Plano GV: The Yersinia pestis YscY protein directly binds $\mathrm{YscX}$, a secreted component of the type III secretion machinery. J Bact 2000, 182:1834-1843.

28. Diepold A, Wiesand U, Amstutz M, Cornelis GR: Assembly of the Yersinia injectisome: the missing pieces. Mol Microbiol 2012, 85:878-892.

29. Urbanowski ML, Lykken GL, Yahr TL: A secreted regulatory protein couples transcription to the secretory activity of the Pseudomonas aeruginosa type III secretion system. Proc Natl Acad Sci USA 2005, 102:9930-9935.

30. Rietsch A, Vallet-Gely I, Dove SL, Mekalanos JJ: ExsE, a secreted regulator of type III secretion genes in Pseudomonas aeruginosa. Proc Natl Acad Sci USA 2005, 102:8006-8011.

31. Urbanowski ML, Brutinel ED, Yahr TL: Translocation of ExsE into Chinese hamster ovary cells is required for transcriptional induction of the
Pseudomonas aeruginosa type III secretion system. Infect Immun 2007, 75:4432-4439.

32. Broberg CA, Calder TJ, Orth K: Vibrio parahaemolyticus cell biology and pathogenicity determinants. Microbes Infect 2011, 13:992-1001.

33. Abby SS, Rocha EPC: The non-flagellar type III secretion system evolved from the bacterial flagellum and diversified into host-cell adapted systems. PLoS Genet 2012, 8:1-15.

34. Erhardt $M$, Namba $K$, Hughes $K T$ : Bacterial nanomachines: the flagellum and type III injectisome. Cold Spring Harb Perspect Biol 2010, 2:1-23.

35. Young GM, Schmiel DH, Miller VL: A new pathway for the secretion of virulence factors by bacteria: The flagellar export apparatus functions as a protein-secretion system. Proc Natl Acad Sci USA 1999, 96:6456-6461.

36. Ehrbar K, Winnen B, Hardt WD: The chaperone binding domain of SopE inhibits transport via flagellar and SPI-1 TTSS in the absence of InvB. Mol Microbiol 2006, 59:248-264.

37. Stone CB, Bulir DC, Gilchrist JD, Toor RK, Mahony JB: Interactions between flagellar and type III secretion proteins in Chlamydia pneumoniae. BMC Microbiol 2010, 10:1-12.

38. Schroeder GN, Hilbi H: Molecular pathogenesis of Shigella spp.: controlling host cell signaling, invasion, and death by type III secretion. Clin Microbiol Rev 2008, 21:134-156.

39. Nilles ML, Williams AW, Skrzypek E, Straley SC: Yersinia pestis LcrV forms a stable complex with LcrG and may have a secretion-related regulatory role in the low-Ca2+ response. J Bact 1997, 179:1307-1316.

40. Chowdhury C, Jagannadham MV: Virulence factors are released in association with outer membrane vesicles of Pseudomonas syringae pv. tomato T1 during normal growth. Biochim Biophys Acta-Proteins and Proteomics 2013, 1834:231-239.

41. Perez-Cruz C, Carrion O, Delgado L, Martinez G, Lopez-Iglesias C, Mercade E: New type of outer membrane vesicle produced by the Gram-negative bacterium Shewanella vesiculosa M7T: implications for DNA content. Appl Environ Microbiol 2013, 79:1874-1881.

42. Akopyan K, Edgren T, Wang-Edgren H, Rosqvist R, Fahlgren A, Wolf-Watz $\mathrm{H}_{\text {, }}$ Fallman M: Translocation of surface-localized effectors in type III secretion. Proc Natl Acad Sci USA 2011, 108:1639-1644.

43. Gonen H, Smith CE, Siegel NR, Kahana C, Merrick WC, Chakraburtty K, Schwartz AL, Ciechanover A: Protein synthesis elongation-factor Ef-1alpha is essential for ubiquitin-dependent degradation of certain $\mathrm{N}$ alpha-acetylated proteins and may be substituted for by the bacterial elongation-factor Ef-Tu. Proc Natl Acad Sci USA 1994, 91:7648-7652.

44. Tsan MF, Gao B: Heat shock proteins and immune system. J Leukoc Biol 2009, 85:905-910.

45. Roberts RJ, Agius C, Saliba C, Bossier P, Sung YY: Heat shock proteins (chaperones) in fish and shellfish and their potential role in relation to fish health: a review. J Fish Dis 2010, 33:789-801.

46. Tamura Y, Torigoe T, Kukita K, Saito K, Okuya K, Kutomi G, Hirata K, Sato N: Heat-shock proteins as endogenous ligands building a bridge between innate and adaptive immunity. Immunotherapy 2012, 4:841-852.

47. Rock KL, York IA, Goldberg AL: Post-proteasomal antigen processing for major histocompatibility complex class I presentation. Nat Immunol 2004, 5:670-677.

48. Kim E, Kwak H, Ahn K: Cytosolic aminopeptidases influence MHC class I-mediated antigen presentation in an allele-dependent manner. J Immunol 2009, 183:7379-7387.

49. Kessler JH, Khan S, Seifert U, Le Gall S, Chow KM, Paschen A, Bres-Vloemans SA, de Ru A, van Montfoort N, Franken KLMC, et al: Antigen processing by nardilysin and thimet oligopeptidase generates cytotoxic T cell epitopes. Nat Immunol 2011, 12:45-67.

50. Neckers L, Tatu U: Molecular chaperones in pathogen virulence: emerging new targets for therapy. Cell Host Microbe 2008, 4:519-527.

51. Kulzer S, Charnaud S, Dagan T, Riedel J, Mandal P, Pesce ER, Blatch GL, Crabb BS, Gilson PR, Przyborski JM: Plasmodium falciparum-encoded exported hsp70/hsp40 chaperone/co-chaperone complexes within the host erythrocyte. Cell Microbiol 2012, 14:1784-1795.

52. Carpousis AJ: The RNA degradosome of Escherichia coli: an mRNAdegrading machine assembled on RNase E. Annu Rev Microbio/ 2007 61:71-87.

53. Rosenzweig JA, Schesser K: Polynucleotide phosphorylase and the T3SS. Adv Exp Med Biol 2007, 603:217-224.

54. Ygberg SE, Clements MO, Rytkonen A, Thompson A, Holden DW, Hinton $J C D$, Rhen M: Polynucleotide phosphorylase negatively controls spv 
virulence gene expression in Salmonella enterica. Infect Immun 2006, 74:1243-1254.

55. Zeng QA, Ibekwe AM, Biddle E, Yang CH: Regulatory mechanisms of exoribonuclease PNPase and regulatory small RNA on T3SS of Dickeya dadantii. Mol Plant Microbe Interact 2010, 23:1345-1355.

56. Kim YR, Brinsmade SR, Yang Z, Escalante-Semerena J, Fierer J: Mutation of phosphotransacetylase but not isocitrate lyase reduces the virulence of Salmonella entetica serovar typhimurium in mice. Infect Immun 2006, 74:2498-2502

57. Deng WY, Yu HB, de Hoog CL, Stoynov N, Li YL, Foster L, Finlay BB: Quantitative proteomic analysis of type III secretome of enteropathogenic Escherichia coli reveals an expanded effector repertoire for attaching/effacing bacterial pathogens. Mol Cell Proteomics 2012, 11:692-709.

58. Zhou XH, Nydam SD, Christensen JE, Konkel ME, Orfe L, Friel P, Call DR: Identification of potential type-III secretion proteins via heterologous expression of Vibrio parahaemolyticus DNA. Appl Environ Microbiol 2012, 78:3492-3494

59. Chaudhuri RR, Peters SE, Pleasance SJ, Northen H, Willers C, Paterson GK Cone DB, Allen AG, Owen PJ, Shalom G, et al: Comprehensive identification of Salmonella enterica serovar typhimurium genes required for infection of BALB/c mice. PLOS Pathog 2009, 5:1-13.

60. Sabbagh SC, Lepage C, McClelland M, Daigle F: Selection of Salmonella enterica serovar typhi genes involved during interaction with human macrophages by screening of a transposon mutant library. PloS One 2012, 7:1-13.

61. Grant AJ, Farris M, Alefounder P, Williams PH, Woodward MJ, O'Connor CD: Co-ordination of pathogenicity island expression by the BipA GTPase in enteropathogenic Escherichia coli (EPEC). Mol Microbiol 2003, 48:507-521.

62. Neidig A, Yeung AT, Rosay T, Tettmann B, Strempel N, Rueger M Lesouhaitier O, Overhage J: TypA is involved in virulence, antimicrobial resistance and biofilm formation in Pseudomonas aeruginosa. BMC Microbiol 2013, 13:77

63. Pridgeon JW, Klesius $\mathrm{PH}$, Song L, Zhang D, Kojima K, Mobley JA Identification, virulence, and mass spectrometry of toxic ECP fractions of West Alabama isolates of Aeromonas hydrophila obtained from a 2010 disease outbreak. Vet Microbiol 2013, 164:336-343.

64. Tanaka KH, Dallaire-Dufresne S, Daher RK, Frenette M, Charette SJ: An insertion sequence-dependent plasmid rearrangement in Aeromonas salmonicida causes the loss of the type three secretion system. Plos One 2012, 7:1-8.

65. Studer N, Frey J, Vanden Bergh P: Clustering subspecies of Aeromonas salmonicida using IS630 typing. BMC Microbio/ 2013, 13:36.

66. Gunasekera K, Wuthrich D, Braga-Lagache S, Heller M, Ochsenreiter T: Proteome remodelling during development from blood to insect-form Trypanosoma brucei quantified by SILAC and mass spectrometry. BMC Genomics 2012, 13:556

67. Al Kaabi A, Traupe T, Stutz M, Buchs N, Heller M: Cause or effect of arteriogenesis: compositional alterations of microparticles from CAD patients undergoing external counterpulsation therapy. PloS One 2012, 7:1-10.

68. Vizcaino JA, Cote RG, Csordas A, Dianes JA, Fabregat A, Foster JM, Griss J, Alpi E, Birim M, Contell J, et al: The Proteomics Identifications (PRIDE) database and associated tools: status in 2013. Nucleic Acids Res 2013, 41:D1063-D1069.

69. Stalder D, Haeberli A, Heller M: Evaluation of reproducibility of protein identification results after multidimensional human serum protein separation. Proteomics 2008, 8:414-424.

70. Gluck F, Hoogland C, Antinori P, Robin X, Nikitin F, Zufferey A, Pasquarello C, Fetaud V, Dayon L, Muller M, et al: EasyProt - An easy-to-use graphical platform for proteomics data analysis. J Proteomics 2013, 79:146-160.

71. Cox J, Mann M: MaxQuant enables high peptide identification rates, individualized p.p.b.-range mass accuracies and proteome-wide protein quantification. Nat Biotechnol 2008, 26:1367-1372.

72. Luber CA, Cox J, Lauterbach H, Fancke B, Selbach M, Tschopp J, Akira S, Wiegand M, Hochrein $\mathrm{H}$, O'Keeffe M, et al: Quantitative proteomics reveals subset-specific viral recognition in dendritic cells. Immunity 2010 32:279-289.

73. Petersen TN, Brunak S, von Heijne G, Nielsen H: SignalP 4.0: discriminating signal peptides from transmembrane regions. Nat Methods 2011, 8:785-786.
74. Bendtsen JD, Nielsen H, Widdick D, Palmer T, Brunak S: Prediction of twinarginine signal peptides. BMC Bioinformatics 2005, 6:167.

75. Lower M, Schneider G: Prediction of type III secretion signals in genomes of gram-negative bacteria. PloS One 2009, 4:1-9.

76. Jehl MA, Arnold R, Rattei T: Effective - a database of predicted secreted bacterial proteins. Nucleic Acids Res 2011, 39:D591-D595.

77. Fichant $G$, Basse MJ, Quentin Y: $A B C d b$ : an online resource for $A B C$ transporter repertories from sequenced archaeal and bacterial genomes. FEMS Microbiol Let 2006, 256:333-339.

78. Zhou Y, Liang Y, Lynch KH, Dennis JJ, Wishart DS: PHAST: a fast phage search tool. Nucleic Acids Res 2011, 39:W347-W352.

doi:10.1186/1477-5956-11-42

Cite this article as: Vanden Bergh et al.: The Aeromonas salmonicida subsp. salmonicida exoproteome: determination of the complete repertoire of Type-Three Secretion System effectors and identification of other virulence factors. Proteome Science 2013 11:42.

\section{Submit your next manuscript to BioMed Central and take full advantage of:}

- Convenient online submission

- Thorough peer review

- No space constraints or color figure charges

- Immediate publication on acceptance

- Inclusion in PubMed, CAS, Scopus and Google Scholar

- Research which is freely available for redistribution 